\title{
Lithium isotopes in island arc geothermal systems: Guadeloupe, Martinique (French West Indies) and experimental approach
}

\author{
Romain Millot (1) ${ }^{*}$, Bruno Scaillet (2) and Bernard Sanjuan (3)
}

(1) BRGM, Metrology Monitoring Analysis Department, Orléans, France

*Corresponding author, e-mail: r.millot@brgm.fr

(2) CNRS/INSU-Université d'Orléans-Université François Rabelais Tours, UMR 6113, Institut des Sciences de la Terre d'Orléans, Orléans, France

(3) BRGM, Department of Geothermal Energy, Orléans, France

\begin{abstract}
We report $\mathrm{Li}$ isotopic measurements in seawater derived waters discharged from geothermal wells, thermal and submarine springs located in volcanic island arc areas in Guadeloupe (the Bouillante geothermal field) and Martinique (Lamentin plain and the Diamant areas). The lithium isotopic signatures of the geothermal fluids collected from deep reservoirs are homogeneous for a given site. However, the $\delta^{7} \mathrm{Li}$ signatures of each of these reservoirs are significantly different. We provide the first low temperature $\left(25-250^{\circ} \mathrm{C}\right)$ experiments of $\mathrm{Li}$ isotope exchange during seawater/basalt interaction), which confirm that $\mathrm{Li}$ isotopic exchange is strongly temperature dependent, as previously inferred from natural studies. $\mathrm{Li}$ isotopic fractionation ranges from $+19.4 \%$ ( $\left.\Delta_{\text {solution - solid }}\right)$ at $25^{\circ} \mathrm{C}$ to $+6.7 \%$ at $250^{\circ} \mathrm{C}$. The experiments also evidence the importance of $\mathrm{Li}$ isotopic fractionation during formation of $\mathrm{Li}$ bearing secondary minerals by the uptake of lithium into the alteration minerals. Application of experimental results to the Bouillante area suggests that the geothermal water is in equilibrium at 250$260^{\circ} \mathrm{C}$ with a deep and large reservoir located in the transition zone possibly at the contact between volcanic flows and basaltic dikes. For the Lamentin and Diamant areas, the geothermal fluid appear to be partially in equilibrium at $90-120^{\circ} \mathrm{C}$ and $180^{\circ} \mathrm{C}$, respectively, with reservoir sedimentary rocks. Our study highlights that lithium isotopic systematics is a powerful tool for the characterization of the origin of geothermal waters as well as the nature of their reservoir rocks.
\end{abstract}

Keywords: lithium isotopes, geothermal water, water/rock interaction, isotope exchange experiments, isotopic fractionation

8472 words (without references and captions) 


\section{INTRODUCTION}

The increasing demand for energy and a desire to increase energy autonomy in the Lesser Antilles (French West Indies) have resulted in a number of BRGM geothermal research projects focused on the islands of Guadeloupe (Traineau et al., 1997; Correia et al., 2000; Sanjuan et al., 2001; Fabriol et al., 2005; Mas et al., 2006) and Martinique (Sanjuan et al., 2002a, 2002b; Genter et al., 2002; Sanjuan et al., 2005) over the past decade.

Such surveys have led to a better understanding of the geothermal systems that are associated with the deep boreholes and thermal springs in these areas (Sanjuan, 2001; Sanjuan et al., 2002a, b). The chemical characterization of thermal water is generally very useful for geothermal exploration. It is also essential if we wish to control water quality, determine its origin and understand the mechanisms of water/rock interaction at high temperature for the purpose of developing geothermal resources.

The chemical composition of geothermal water in terms of reactive major and trace elements is related to the intensity of water/rock interaction and to the mineralogical assemblage of the surrounding rocks. Classical geothermometers, such as dissolved silica, $\mathrm{Na-K}, \mathrm{Na}-\mathrm{K}-\mathrm{Ca}$ or K-Mg applied to geothermal waters (Fournier and Rowe, 1966; Fournier and Truesdell, 1973; Michard, 1979; Fournier, 1979; Giggenbach, 1988; Michard, 1990), enable to estimate the temperature of the deep reservoirs feeding geothermal fields. However, the values estimated for such temperatures are not always consistent with each other. The three $\mathrm{Na} / \mathrm{Li}$ thermometric relationships (Fouillac and Michard, 1981; Kharaka et al., 1982; Kharaka and Mariner, 1989), differ from classical geothermometers in that they associate a major (sodium) and a trace element (lithium), the latter of which giving an additional temperature constraint. Owing to the relatively low reactivity of Li during ascent to the surface, these thermometric relationships appear to be very reliable, as well as useful tools for characterizing the source (i.e. deep conditions) of geothermal waters.

The main objective of the present work is to better understand the behavior of Li within an island arc geothermal environment by using the isotopic systematics of $\mathrm{Li}$ in order to improve geothermal reservoir exploration and associated characterization methods. In this context, one particularly important aspect is to establish the nature, extent and mechanism of $\mathrm{Li}$ isotope fractionation as a function of temperature during water/rock interaction.

Lithium is a chemical element with two isotopes of mass 6 and 7, with natural abundances of $7.5 \%$ and $92.5 \%$, respectively. Lithium is a fluid-mobile element that tends to preferentially partition into the fluid phase during water/rock interaction. The relative mass difference between the two isotopes is considerable (17\%) and is likely to generate large mass dependent fractionation during geochemical processes, even at high temperature. The range 
of variation in $\mathrm{Li}$ isotopic compositions is more than $50 \%$ in geological materials (Coplen et al., 2002; Tomascak, 2004).

In this study, we measured the Li isotopic composition of various water samples (geothermal waters, thermal springs and submarine thermal springs). Li concentration and isotope composition of the geothermal fluids are a function of many parameters, namely the compositions of the water and rock, water/rock ratio, mineral-fluid partition and mineral-fluid isotopic fractionation, the last two being temperature dependent. In order to disentangle the relative importance of each of these parameters, we have performed laboratory simulations of $\mathrm{Li}$ isotopic behavior during water/rock interaction over a temperature range $\left(25-250^{\circ} \mathrm{C}\right)$. These experimental results are then applied to natural systems to infer the origin of the waters and reservoir rock compositions.

\section{GEOTHERMAL SETTING}

Guadeloupe and Martinique are volcanic islands belonging to the Lesser Antilles arc (Fig. 1). Samples of geothermal waters were collected at 3 different sites: 1- the Bouillante area (Guadeloupe), 2- the Lamentin area (Martinique) and 3- the Diamant area (Martinique).

\subsection{Bouillante area}

The Bouillante geothermal area is located on the west coast of Basse-Terre (Guadeloupe, Fig. 1). The area is developed near the seaside and around the town of Bouillante, where there are numerous hydrothermal vents such as hot springs, mud pools, steaming ground and fumaroles (in French, 'bouillante' means 'boiling'; Traineau et al., 1997).

Most of the active geothermal manifestations are located south of Bouillante Bay, around the geothermal power plant, where deep wells BO-2, BO-4, BO-5 and BO-6 are located. Between 1996 and 2002, only BO-2 was productive (150 tons/h of fluid including 30 tons/h of steam). Since 2005, the new geothermal power plant has been fed by wells BO-4, BO-5 and BO-6 (a maximum production of about 570 tons/h of fluid including 115 tons $/ \mathrm{h}$ of steam). There are also numerous submarine hot springs, especially north of Bouillante Bay (Traineau et al., 1997; Sanjuan, 2001).

Geochemical characterization has provided the following information about the Bouillante geothermal field: the water flowing through the geothermal reservoir, whether sampled in wells or hot springs, has a homogeneous composition at the scale of the Bouillante region (Traineau et al., 1997; Sanjuan et al., 2001). The geothermal $\mathrm{NaCl}$ fluid (TDS $\approx 20 \mathrm{~g} / \mathrm{L}, \mathrm{pH}=$ 5.3 ) is the result of the mixing of about $58 \%$ seawater and $42 \%$ fresh water. The fresh surface water is probably fed by rainfall on the western side of the island (Pitons de 
Bouillante). The amount of associated incondensable gases, made up predominantly (90$95 \%)$ of $\mathrm{CO}_{2}$, is low (<0.1\% in mass).

The homogeneity of the chemical and isotopic compositions of the geothermal fluids and the convergence of chemical geothermometers such as Silica-Quartz, $\mathrm{Na} / \mathrm{K}$ and K/Mg (Fournier and Rowe, 1966; Fournier, 1979; Michard, 1979; Giggenbach, 1988) toward a maximum temperature value of around $250-260^{\circ} \mathrm{C}$, all suggest the existence of a common large deep reservoir whose volume was estimated to be higher than 30 millions $\mathrm{m}^{3}$ using tracer test results. The $\mathrm{Na} / \mathrm{Li}$ geothermometer determined by Fouillac and Michard (1981) for saline geothermal waters in volcanic and granitic environments gives a temperature value of $224^{\circ} \mathrm{C}$, similar to that obtained using the $\mathrm{Na} / \mathrm{K} / \mathrm{Ca}$ geothermometer $\left(226^{\circ} \mathrm{C}\right.$; Fournier and Truesdell, 1973), but slightly lower than those either measured inside the geothermal wells or estimated using classical geothermometers. Geochemical modeling has shown that the reservoir fluid is in chemical equilibrium with a mineralogical assemblage made up of albite, K-feldspar, quartz, calcite, disordered dolomite, anhydrite, illite, smectite and zeolites at $250-260^{\circ} \mathrm{C}$ (Sanjuan et al., 2001).

\subsection{Lamentin plain}

The Lamentin plain, on the western coast of Martinique (Fig. 1), south of Fort de France, is an alluvial plain with a surface area of approximately $100 \mathrm{~km}^{2}$. The Lamentin area corresponds to a major graben zone limited by NW-SE faults and intersected by NE-SW faults. There are numerous thermal springs aligned along an axis oriented NNW-SSE to NW$\mathrm{SE}$ in the area. Their flow rate is generally low and they are characterized by the presence of $\mathrm{CO}_{2}$-rich $\mathrm{NaCl}$ fluids (Sanjuan et al., 2002a, b), with exit temperatures ranging from 37 to $58^{\circ} \mathrm{C}$.

Three boreholes were drilled at a depth of $1000 \mathrm{~m}$ in this area in 2001 . Only the borehole Californie, located farther north, indicated the presence of hot fluid close to $90^{\circ} \mathrm{C}$ at a depth of $400 \mathrm{~m}$. A fluid with a similar chemical composition but with a lower temperature $\left(50^{\circ} \mathrm{C}\right)$ was also found at a depth of about $400 \mathrm{~m}$ in the borehole Carrère, near thermal springs.

The geochemical study of the fluids collected from these exploration boreholes and thermal springs suggests that the current hydrothermal system is concentrated in the north in relation to a general outflow coming from the NW and at relatively deep depths. The geothermal $\mathrm{NaCl}$ fluid, made up of about $30 \%$ seawater and $70 \%$ freshwater (TDS $\approx 10-11 \mathrm{~g} / \mathrm{L} ; \mathrm{pH}=6.2$ ) and accompanied mainly by magmatic $\mathrm{CO}_{2}$ gas, probably comes from a reservoir located close to seawater. Chemical geothermometers such as Silica-Chalcedony, $\mathrm{Na} / \mathrm{K} / \mathrm{Ca} / \mathrm{Mg}, \mathrm{K} / \mathrm{Mg}$ (Arnorsson and Gunnlaugsson, 1983; Fournier and Potter, 1979; Giggenbach, 1988) suggest reaction with volcano-sedimentary rocks at temperatures ranging from 90 to $120^{\circ} \mathrm{C}$. which 
are identical to the maximum value $\left(90-100^{\circ} \mathrm{C}\right.$ ) measured in the boreholes (Sanjuan et al., 2002a; 2002b). The $\mathrm{Na} / \mathrm{K}$ and $\mathrm{Na} / \mathrm{K} / \mathrm{Ca}$ geothermometers (Michard, 1979; Fournier, 1979; Fournier and Truesdell, 1973) yield higher temperatures. Concerning the $\mathrm{Na} / \mathrm{Li}$ geothermometer, only the relationship determined by Kharaka et al. (1982) for waters from world geothermal and US oil sedimentary basins yields temperatures close to that measured in the boreholes (Sanjuan et al., 2002a; 2002b). This result thus strongly suggest the importance of a sedimentary signature in the reservoir rocks.

\subsection{Diamant area}

The Diamant area is located in southern Martinique (Fig. 1). An extensive survey of gas and water geochemistry (Sanjuan et al., 2003; 2005) confirmed the presence of zones of hightemperature of geothermal interest. In this area, the only thermal spring (Petite Anse) has several discharge points near the seaside from which two water samples were collected (DIAM1 and DIAM2). The main emergence (DIAM1) has a temperature close to $35^{\circ} \mathrm{C}$ at the surface. The deep geothermal $\mathrm{NaCl}$ fluid, discharged from this emergence, has a high salinity (TDS $\approx 20 \mathrm{~g} / \mathrm{L}$ ) and a $\mathrm{pH}$ value close to 5.3. Abundant magmatic $\mathrm{CO}_{2}$ gas emanations are associated with this fluid (Sanjuan et al., 2003; 2005). The location of the thermal spring, the nature of this fluid and its high salinity, all suggest a marine origin, and its exceedingly low $\delta \mathrm{D}$ value $(-22 \%)$ compared to other values observed in the fluids of Martinique and the Lesser Antilles, also point out a magmatic contribution.

The geochemical characteristics of this fluid, and especially the use of chemical geothermometers such as Silica-Quartz, $\mathrm{Na} / \mathrm{K}, \mathrm{Na} / \mathrm{K} / \mathrm{Ca}$ or isotopic geothermometers such as $\delta^{18} \mathrm{O}\left(\mathrm{H}_{2} \mathrm{O}-\mathrm{SO}_{4}\right)$ (Fournier and Rowe, 1966; Fournier, 1979; Fournier and Truesdell, 1973; Mizutani and Rafter, 1969), enabled us the identification of a geothermal reservoir at about $180^{\circ} \mathrm{C}$ (Sanjuan et al., 2003; 2005). As for the Lamentin geothermal fluid, only the $\mathrm{Na} / \mathrm{Li}$ relationship determined by Kharaka et al. (1982) gives temperature values in agreement with that estimated for the reservoir fluid, again suggesting the importance of a sedimentary signature in the reservoir rocks.

\section{ANALYTICAL METHODS}

\subsection{Major and trace elements}

All the chemical analyses were carried out in the BRGM laboratories using standard water analysis techniques such as ion chromatography, atomic absorption spectrophotometry, inductively coupled plasma mass spectrometry (ICP-MS), colorimetry, ion electrode and 
titration. The accuracy of the major species is better than $\pm 5 \%$. Alkalinity was determined in the field following $\mathrm{HCl}$ titration and Gran's method. Ion balance values lower than $5 \%$ suggest a good quality for the analyses of the major species. Lithium concentrations in geothermal waters were determined by ICP-MS (accuracy $\pm 5 \%$ ).

Water samples for $\mathrm{Li}$ isotopic determination were collected in acid-washed polyethylene bottles and then filtered through pre-washed $0.2 \mu \mathrm{m}$ Sartorius cellulose filters using a cleaned polycarbonate Sartorius apparatus under nitrogen. Samples were acidified with ultra pure nitric acid down to $\mathrm{pH} \sim 2$.

\subsection{Lithium isotopes}

Lithium isotopic compositions were measured using a Neptune Multi Collector ICP-MS (Thermo Fischer Scientific). ${ }^{7} \mathrm{Li} /{ }^{6} \mathrm{Li}$ ratios were normalized to the L-SVEC standard solution (NIST SRM 8545, Flesch et al., 1973) following the standard-sample bracketing method (see Millot et al., 2004 for more details). Typical in-run precision on the determination of $\delta^{7} \mathrm{Li}$ is about $0.2 \%$ o $\left(2 \sigma_{m}\right)$.

The samples must be prepared beforehand with chemical separation/purification by ion chromatography in order to produce a pure mono-elemental solution. Chemical separation of $\mathrm{Li}$ from the matrix was achieved before the mass analysis following a procedure modified from the technique of James and Palmer (2000) using a cationic resin (a single column filled with $3 \mathrm{~mL}$ of BioRad $A G \AA 50 \mathrm{~W}-X 12$ resin, 200-400 mesh) and $\mathrm{HCl}$ acid media $(0.2 \mathrm{~N})$ for 30 $\mathrm{ng}$ of $\mathrm{Li}$. Blanks for the total chemical extraction were less than $30 \mathrm{pg}$ of $\mathrm{Li}$, which is negligible since it represents a $10^{-3}$ blank/sample ratio.

Accuracy and reproducibility of the entire method (purification procedure + mass analysis) were tested by repeated measurement of a seawater sample (IRMM BCR-403) after separation of $\mathrm{Li}$ from the matrix, for which we obtained a mean value of $\delta^{7} \mathrm{Li}=+30.8 \% \pm 0.4$ $(2 \sigma, n=15)$ over the period of the duration of the analyses. This mean value is in good agreement with our long-term measurement $\left(\delta^{7} \mathrm{Li}=+31.0 \% \pm 0.5,2 \sigma, \mathrm{n}=30\right.$, Millot et al., 2004) and with other values reported in the literature (see, for example, Tomascak 2004 for a compilation). For rocks, a total digestion of the sample is necessary before separation of $\mathrm{Li}$ from the matrix. About $50 \mathrm{mg}$ of crushed sample was dissolved in a closed beaker with an ultrapure mixture of three acids for 4 days at $100^{\circ} \mathrm{C}: 4 \mathrm{ml}$ of $\mathrm{HF}(23 \mathrm{~N}), 1 \mathrm{ml}$ of $\mathrm{HNO}_{3}(14 \mathrm{~N})$ and $0.1 \mathrm{ml}$ of $\mathrm{HClO}_{4}(12 \mathrm{~N})$. Four days later, after the acid mixture had evaporated, $4 \mathrm{ml}$ of $\mathrm{HCl}$ acid $(6 \mathrm{~N})$ was added for 4 days at $100^{\circ} \mathrm{C}$. A sample aliquot (30 $\mathrm{ng}$ of $\mathrm{Li}$ ) of the residue of the acid dissolution was then dissolved in $0.5 \mathrm{ml}$ of $\mathrm{HCl}(0.2 \mathrm{~N})$ before being placed in a column containing cationic resin for $\mathrm{Li}$ separation. Accuracy and reproducibility of the 
procedure for solid samples (dissolution + purification procedure + mass analysis) was tested by repeated measurement of the JB-2 basalt standard (Geological Survey of Japan) and gave a mean value of $\delta^{7} \mathrm{Li}=+4.9 \%$ o $\pm .6(2 \sigma, \mathrm{n}=17)$ which is in good agreement with published values (see Carignan et al., 2007 and Tomascak 2004 for data compilation).

\subsection{Experimental techniques for seawater/basalt interaction}

In order to determine the extent of $\mathrm{Li}$ isotope fractionation during water/rock interaction as a function of temperature, we performed laboratory experiments. These experiments consisted of determining $\mathrm{Li}$ isotopic fractionation during the interaction of basalt with seawater at different temperatures $\left(25^{\circ}, 75^{\circ}, 200^{\circ}\right.$ and $\left.250^{\circ} \mathrm{C}\right)$ and various pressures. This is the first study involving $\mathrm{Li}$ isotope exchange experiments for low temperature water/rock interaction (below $100^{\circ} \mathrm{C}$ ).

The basalt chosen for the experiments is the JB-2 tholeiitic basalt (Japan Geological Survey), which is a well characterized secondary reference material for $\mathrm{Li}$ isotopes and $\mathrm{Li}$ concentration $\left(\delta^{7} \mathrm{Li}=+4.9 \% \pm \pm 0.6, \mathrm{Li}=7.78 \mu \mathrm{g} / \mathrm{g}\right.$ ). The seawater chosen for the experiments is the reference material IRMM BCR-403 $\left(\delta^{7} \mathrm{Li}=+31.0 \% \pm 0.5, \mathrm{Li}=0.18 \mathrm{mg} / \mathrm{L}\right.$, Millot et al., 2004).

The experiments were carried out with a seawater/basalt mass ratio of 10 and a seawater solution diluted to $60 \%$ (with ultrapure $\mathrm{H}_{2} \mathrm{O}$ Milli- $\mathrm{Q}^{\circledR}$ ) in order to reproduce the natural conditions (water/rock ratio and seawater dilution) that are found in the Bouillante geothermal site.

Run durations varied from days to weeks depending on the applied temperature (Table 1). Lithium concentration and $\mathrm{Li}$ isotope composition $\left(\delta^{7} \mathrm{Li}\right)$ were measured through time in sampled aliquots of the solution having interacted with the basalt at various temperatures $\left(25^{\circ}, 75^{\circ}, 200^{\circ}\right.$ and $\left.250^{\circ} \mathrm{C}\right)$.

Two different experimental devices were used. For experiments carried out at $25^{\circ}, 75^{\circ}$ and $200^{\circ} \mathrm{C}$, large volumes ( 5 to $10 \mathrm{ml}$ ) of solution were put into closed beakers and then placed in an oven. For experiments carried out at $200^{\circ}$ and $250^{\circ} \mathrm{C}$, small volumes of solution $(300 \mu \mathrm{l})$ were loaded in gold capsules and then placed in an autoclave. We were, therefore, able to compare the results obtained from the two devices at $200^{\circ} \mathrm{C}$.

For experiments at $25^{\circ}$ and $75^{\circ} \mathrm{C}, 5 \mathrm{ml}$ of diluted seawater were initially placed with $500 \mathrm{mg}$ of powdered JB-2 basalt in a closed Teflon ${ }^{\circledR}$ PFA beaker and then placed in a thermocontrolled oven, with temperatures set at $25^{\circ}$ or $75^{\circ} \mathrm{C}$. The temperature inside the oven varied less than $5 \%$ over the total duration of the experiments. The solution was sampled after 2 days and then after 1, 5, 10 and 35 weeks (Table 1$)$ and the samples (300 $\mu \mathrm{l})$ were 
filtered at $0.20 \mu \mathrm{m}$ before $\mathrm{Li}$ isotopic measurement in order to ensure that only dissolved $\mathrm{Li}$ is sampled, without any contribution of powdered basalt.

At $200^{\circ} \mathrm{C}, 10 \mathrm{ml}$ of diluted seawater with $1 \mathrm{~g}$ of powdered JB-2 basalt was put in a Teflon ${ }^{\circledR}$ PTFE bomb within a screw-top stainless-steel container and then placed in an oven at $200^{\circ} \mathrm{C}$. Solution aliquots $(300 \mu \mathrm{l}$ filtered) were sampled after 3 and 7 days.

Experiments were also carried out at $200^{\circ}$ and $250^{\circ} \mathrm{C}$ in an autoclave furnace system under high pressure at the Institut des Sciences de la Terre d'Orléans (ISTO). Diluted seawater $(300 \mu \mathrm{l})$ and powdered basalt $(30 \mathrm{mg})$ were loaded in gold capsules $(4 \mathrm{~cm}$ long, $5 \mathrm{~mm}$ in diameter) previously cleaned by boiling in diluted $\mathrm{HCl}$ solution and then in distilled water. The powdered basalt was placed at the bottom of the gold capsule before the diluted seawater was added. Once filled with diluted seawater, the capsules were welded shut using a graphite arc welder. The weight of the capsules was used to monitor loss during welding. The capsules were then placed in an internally heated pressure vessel pressurized with $\mathrm{Ar}$ (Scaillet et al., 1992) at either $200^{\circ}$ or $250^{\circ} \mathrm{C}(\mathrm{P}=150$ bar). Run durations varied between 1 and 12 days (Table 1 ), during which the temperature remained within $1^{\circ} \mathrm{C}$ of the target value, whilst pressure fluctuations related to changes in room temperature were less than 5 bars. Overall, the uncertainties in temperature and pressure values reported here are estimated to be $\pm 5^{\circ} \mathrm{C}$ and \pm 5 bar. Upon completion of the run, capsules were removed from the vessel, weighed to check for leaks and opened. The sampled solution was then filtered at $0.2 \mu \mathrm{m}$. No experiments showed weight changes in excess of $0.2 \mathrm{mg}$, which is within the analytical uncertainty of the balance.

Possible contamination for experiments using Teflon ${ }^{\circledR}$ PFA beakers $\left(25^{\circ}\right.$ and $\left.75^{\circ} \mathrm{C}\right)$, Teflon $^{\circledR}$ PTFE bomb $\left(200^{\circ} \mathrm{C}\right)$ and gold capsules $\left(200^{\circ}\right.$ and $\left.250^{\circ} \mathrm{C}\right)$ was tested by running diluted seawater without powdered basalt for several days and by comparing Li concentration and $\delta^{7} \mathrm{Li}$ values before and after run completion. This clearly showed that there is no variation in either the $\mathrm{Li}$ concentration $(0.1 \mathrm{mg} / \mathrm{L}, 60 \%$ diluted $)$ or $\delta^{7} \mathrm{Li}$ values $\left({ }^{7} \mathrm{Li}=+31.0 \%\right)$, meaning that there was no Li contamination from containers or handling.

At the end of each experiment $\left(25^{\circ}, 75^{\circ}, 200^{\circ}\right.$ and $\left.250^{\circ} \mathrm{C}\right)$, $\mathrm{Li}$ isotope compositions $\left(\delta^{7} \mathrm{Li}\right)$ were measured in the solid products, in order to determine the $\mathrm{Li}$ isotope fractionation between the liquid and the solid phase.

\subsection{Mineral characterization}

The residual solids (powdered basalt after interaction) were analyzed at the end of each experiment $\left(25^{\circ}, 75^{\circ}, 200^{\circ}\right.$ and $250^{\circ} \mathrm{C}$.). Transmission Electron Microscopy (TEM) was performed at the University of Orléans to determine the bulk mineralogical composition of the residual solid after interaction. In addition, infrared spectra were obtained on a BRUKER Equinox IFS55 Fourier Transform Infrared Spectrometer (FTIR spectrometry) by 
transmission through a pellet of a mixture of $150 \mathrm{mg} \mathrm{KBr}$ with less than $1 \mathrm{mg}$ of sample. The spectrometer is equipped with a high energy source, separating $\mathrm{KBr}$ and a DTGS detector making it possible to explore the infra-red average ranging classically from 4000 to $350 \mathrm{~cm}^{-1}$. The spectral resolution is $4 \mathrm{~cm}^{-1}$, with 32 scans used for both the background and for the samples.

\section{RESULTS}

\subsection{Bouillante, Lamentin and Diamant areas}

Lithium concentrations span almost two orders of magnitude in the water samples collected from the Bouillante area, ranging from $0.19 \mathrm{mg} / \mathrm{L}$ for the sub-marine spring SM5 to $6.7 \mathrm{mg} / \mathrm{L}$ for the deep geothermal water (well BO-6). The fluids from the wells have the highest $\mathrm{Li}$ concentrations, ranging from 4.3 to $6.7 \mathrm{mg} / \mathrm{L}$ depending on the sampling conditions (downhole sampling, sampling after phase separator, sampling in the weir box; see Table 2). Generally, the down-hole water sample is representative of the deep fluid. The increasing concentrations observed for most of the chemical species (including $\mathrm{Li}$ ) in the samples of residual fluid collected at the surface (after separator or in the weir box) are the result of the formation and loss of steam, the amount of which depends on the temperature and pressure conditions of the phase separation.

Lithium isotopic compositions $\left(\delta^{7} \mathrm{Li}\right)$ are also very variable and range from +3.8 for the BO-BS water sample to $+29.3 \%$ for the seawater sample respectively. However, it is important to note that all the well fluids in the Bouillante geothermal field (BO-2, BO-4, BO-5 and BO-6 samples) have similar $\delta^{7} \mathrm{Li}$ values. These geothermal water samples were collected from the various wells intersecting the deep reservoir and under different sampling conditions (from 1999 to 2002). They present $\delta^{7}$ Li signatures between +4.2 and $+4.8 \%$, with an average value of $\delta^{7} \mathrm{Li}=+4.4 \%$ o $\pm 0.4(2 \sigma, \mathrm{n}=8)$. This constancy in $\delta^{7} \mathrm{Li}$ values $( \pm 0.4 \%$, close to the reproducibility of the analytical determination of $\delta^{7} \mathrm{Li}$ ) clearly shows that geothermal fluids discharged from the wells are homogeneous from a $\mathrm{Li}$ isotope point of view and, consequently, that all of the geothermal wells are probably fed by a common reservoir.

These conclusions are in agreement with the homogeneity observed from the chemical analyses and other isotopic analyses ( $\delta \mathrm{D}$ and $\delta^{18} \mathrm{O}$ values, boron and strontium isotopes; Sanjuan et al., 2001; Mas et al., 2006). Our results show that no Li isotopic fractionation occurs (or is negligible) during the phase separation between liquid and steam, under different temperature and pressure conditions (after separator: $160^{\circ} \mathrm{C}$ and 6-8 bar; in weir 
box: $100^{\circ} \mathrm{C}$ and 1 bar, see Table 2). For instance, the $\delta^{7} \mathrm{Li}$ value determined in a sample of separated steam is $\delta^{7} \mathrm{Li}=+4.8 \%$, (sample BO-4-00-222C, Table 2), identical to the $\delta^{7} \mathrm{Li}$ value prior to phase separation. In addition to that, the BO-BS water samples that were collected from a shallow borehole also yield $\delta^{7} \mathrm{Li}$ values $(+3.8$ and $+4.2 \%$ ) similar to those measured in the fluids discharged from the geothermal wells. The overall chemical and isotopic results $\left(\delta \mathrm{D}, \delta^{18} \mathrm{O},{ }^{87} \mathrm{Sr} /{ }^{86} \mathrm{Sr}\right)$ therefore suggest that these samples consist mainly of geothermal reservoir fluid, which can be slightly diluted by shallow freshwater before vaporizing as it rises to the surface and cools.

The fluids discharged from the submarine thermal springs have $\delta^{7} \mathrm{Li}$ signatures ranging from +4.8 to $+26.1 \%$ (sample SM5 having the highest $\delta^{7} \mathrm{Li}$ value). The value for seawater sampled offshore in the Bouillante bay $\left(\delta^{7} \mathrm{Li}=+29.3 \%\right)$ is at the lower end of the range of variation observed for oceans worldwide (from +29 to $+34 \%$, Millot et al., 2004).

For the Lamentin plain (Martinique), lithium concentrations in the water samples range from $0.23 \mathrm{mg} / \mathrm{L}$ (seawater) to $1.67 \mathrm{mg} / \mathrm{L}$ (borehole Carrère, Table 2). The geothermal water samples collected from the two boreholes are different with $\delta^{7} \mathrm{Li}=+7.8 \%$ or the borehole Californie and +6.0 and $+6.2 \%$ for the borehole Carrère respectively. The seawater sampled near the Lamentin area has a $\mathrm{Li}$ isotopic composition of $\delta^{7} \mathrm{Li}=+30.1 \%$, in good agreement with the average value of seawater.

In the Diamant area, $\mathrm{Li}$ concentrations range from $0.226 \mathrm{mg} / \mathrm{L}$ (seawater) to $10.1 \mathrm{mg} / \mathrm{L}$ (thermal water sample DIAM1). The lithium isotopic range is very large with $\delta^{7} \mathrm{Li}$ values between +6.2 and $+30.5 \%$ for the DIAM1 sample and the seawater sample, respectively. The water samples collected from the two discharge points of the thermal spring Petite Anse (DIAM1 and DIAM2; Fig. 1) present a $\mathrm{Li}$ isotopic composition in the range of +6.2 to $+7.1 \%$.

\subsection{Seawater/basalt interaction experiments}

The lithium concentration and isotopic composition of the solutions were determined after various reaction times during seawater/basalt interaction at $25^{\circ}, 75^{\circ}, 200^{\circ}$ and $250^{\circ} \mathrm{C}$. Results are given as a function of reaction time and interaction temperature (Table 1). For the liquid phase, lithium concentrations and $\delta^{7} \mathrm{Li}$ variation with time are plotted against temperature including the initial seawater (diluted to 60\%) having a Li concentration of 100 $\mu \mathrm{g} / \mathrm{L}$ and a $\delta^{7} \mathrm{Li}$ value of $+31.0 \%$, (Fig. 2).

At $25^{\circ} \mathrm{C}$, the seawater/basalt interaction was measured in liquid samples collected after 2,7 , 35,70 and 245 days. Starting with an initial value of $100 \mu \mathrm{g} / \mathrm{L}$, the $\mathrm{Li}$ concentration varies little throughout the experiment with values between 97 and $123 \mu \mathrm{g} / \mathrm{L}$. According to the uncertainty of the method used to measure Li concentration after run completion, there is 
little variation of $\mathrm{Li}$ concentration in solution during the interaction of basalt with seawater at $25^{\circ} \mathrm{C}$. On the other hand, starting with an initial value of $\delta^{7} \mathrm{Li}=+31.0 \%$, the $\mathrm{Li}$ isotopic composition of the solution decreases rapidly and significantly to reach a $\delta^{7} \mathrm{Li}$ value of $+23.5 \%$ after 245 days.

At $75^{\circ} \mathrm{C}$, sample aliquots were collected after 2, 7, 35, 70 and 245 days. The lithium concentration increases steadily with time up to $220 \mu \mathrm{g} / \mathrm{L}$ (twice the initial value). Associated with this increase of $\mathrm{Li}$ in solution, $\delta^{7} \mathrm{Li}$ values in the solution decrease. The $\delta^{7} \mathrm{Li}$ signature drops from $+31.0 \%$ to $+16.5 \%$ after 245 days.

At $200^{\circ} \mathrm{C}$, Li concentration significantly increases in solution during seawater/basalt interaction both in experiments carried out with the PTFE bomb and in those completed with gold capsules in an autoclave. This increase is observed after 1 day of interaction $(212 \mu \mathrm{g} / \mathrm{L})$, after which $\mathrm{Li}$ concentration does not vary appreciably (Fig. 2). The lithium isotopic composition of the solution decreases rapidly and significantly down to a minimum $\delta^{7} \mathrm{Li}$ value of around $+14.5 \%$. Values are identical for both the PTFE-bomb and gold-capsules methods $\left(+14.2 \%\right.$ to $+14.7 \%$ ). The fact that the same $\delta^{7} \mathrm{Li}$ values are obtained with both methods and that the $\delta^{7} \mathrm{Li}$ signature is constant with time shows that steady state is probably reached for $\mathrm{Li}$ isotopes exchange. The lithium isotopic signature is $\delta^{7} \mathrm{Li}=+15.2 \%$ after 12 days, identical to $+14.5 \%$ considering the reproducibility of the method: $\pm 0.5 \% 0(2 \sigma)$.

At $250^{\circ} \mathrm{C}$, Li concentration rapidly increases in solution and tends to a maximal value of 352 $\mu \mathrm{g} / \mathrm{L}$ after 7 days (more than 3 times the initial value of $100 \mu \mathrm{g} / \mathrm{L}$ ). Li isotope variation at $250^{\circ} \mathrm{C}$ shows a strong decrease from $+31.0 \%$ down to $+13.1 \%$ after 1 day, after which values are constant with $+11.7 \%$ and $+11.6 \%$ after 2 and 7 days, respectively.

In addition to the fluid, the $\mathrm{Li}$ isotopic composition of the residual solid (powdered basalt after interaction) was analyzed at the end of each experiment $\left(25^{\circ}, 75^{\circ}, 200^{\circ}\right.$ and $250^{\circ} \mathrm{C}$.). These

$\delta^{7} \mathrm{Li}$ values (Table 3 ) are identical to the initial value measured for the JB-2 basalt, showing that there is no measurable variation in the $\mathrm{Li}$ isotopic composition of bulk solid phase during these experiments, which reflects the order of magnitude difference in $\mathrm{Li}$ concentrations between starting solid and fluid.

\section{DISCUSSION}

\subsection{Li isotopic systematics in geothermal systems}

A graph of the $\mathrm{Li}$ isotopic composition $\left(\delta^{7} \mathrm{Li}\right)$ of the various waters from the Bouillante geothermal area plotted against their $\mathrm{Li} / \mathrm{Cl}$ ratio (Fig. 3 ), reveals the mixing process (shown 
by hyperbolic curve on the graph) and highlights samples having the highest $\mathrm{Li} / \mathrm{Cl}$ ratios (i.e. those enriched in $\mathrm{Li}$ ), which are the samples of interest for the study of geothermal systems. As stressed above, the most important result is that all of the deep geothermal fluids from the Bouillante area (BO-2, BO-4, BO-5, BO-6 and BO-BS) have very homogeneous $\mathrm{Li}$ isotopic signatures, with an average value of $\delta^{7} \mathrm{Li}=+4.4 \% \pm \pm 0.5$. These well fluids also correspond to the samples with the highest $\mathrm{Li} / \mathrm{Cl}$ ratios (from $3.7 \times 10^{-4}$ to $4.1 \times 10^{-4}$ ) and belong to the Bouillante geothermal reservoir for which a deep temperature was estimated at $250-260^{\circ} \mathrm{C}$.

On the other hand, it is apparent that the fluid samples collected from the submarine thermal springs define a good mixing trend between a geothermal reservoir fluid and seawater, the latter having a high $\mathrm{Li}$ isotopic signature of $\delta^{7} \mathrm{Li}=+29.3 \%$ and a low $\mathrm{Li} / \mathrm{Cl}$ ratio of $0.1 \times 10^{-4}$. This mixing process has already been reported on the basis of major element concentrations by Traineau et al. (1997), Sanjuan and Brach (1997) and Sanjuan et al. (2001), and is confirmed here by the use of $\mathrm{Li}$ isotopes tracing.

The geothermal waters of the Lamentin area, which are initially made up of a mixture of seawater and fresh surface water, are significantly different compared to Bouillante samples with respect to their $\mathrm{Li}$ isotope signature, with $\delta^{7} \mathrm{Li}=+7.8 \%$ of the borehole Californie and +6.0 and $+6.2 \%$ for the two Carrère boreholes. These fluids correspond to the Lamentin geothermal reservoir with an average value of $\delta^{7} \mathrm{Li}=+6.7 \%$ o $(n=3)$, the deep temperature of which was estimated to be between $90^{\circ}$ and $120^{\circ} \mathrm{C}$. The $\mathrm{Li}$ isotopic signature of the Lamentin geothermal reservoir is, therefore, very different from that of Bouillante.

Figure 3 shows the waters collected from wells and submarine thermal springs in both the Bouillante and Lamentin geothermal sites for comparison. The hyperbolic curves for mixing of deep reservoir fluids and seawater are also shown for each geothermal system, illustrating that the Bouillante and Lamentin geothermal reservoirs are very different in terms of both their $\mathrm{Li}$ isotopic signature and their $\mathrm{Li} / \mathrm{Cl}$ ratios and this is probably results from the difference in temperatures of the reservoir sources $\left(90-120^{\circ} \mathrm{C}\right.$ for Lamentin and $250-260^{\circ} \mathrm{C}$ for Bouillante). Indeed, at higher temperature, it is likely that more $\mathrm{Li}$ is released to the geothermal water thus lowering the $\delta^{7} \mathrm{Li}$ signature of the water, which would trend toward that of the interacting reservoir rocks. The extent of $\mathrm{Li}$ isotope fractionation as a function of temperature during water/rock interaction will be discussed in paragraph 5.2. Alternatively, these $\mathrm{Li}$ isotopic signatures might also result from differences in the lithology and nature of the reservoir rocks at the two sites.

In what concerns the Diamant area, the comparison of the chemical compositions of samples DIAM1 and DIAM2 indicates a dilution by fresh surface water. The origin of these saline thermal waters seems to be relatively complex (Sanjuan et al., 2003; 2005). Their $\delta^{7} \mathrm{Li}$ signatures, however, are similar at the $2 \sigma$ level $(+6.8$ and $+6.2 \%$ for DIAM $1,+7.1$ and $+6.6 \%$ o 
for DIAM2 respectively) which suggest that they are coming from the same geothermal reservoir at $180^{\circ} \mathrm{C}$.

\subsection{Lithium isotopic fractionation and temperature dependence}

\subsubsection{Lithium isotope exchange experiments}

Experiments were carried out at different temperatures to investigate $\mathrm{Li}$ isotope exchange between a diluted seawater solution and a powdered basalt. The evolution with time of $\mathrm{Li}$ concentrations in solution clearly indicates a temperature dependence of lithium and its isotopes (Fig. 2 and section 4.2.). Indeed, the release of $\mathrm{Li}$ into solution for each experiment increases with temperature. In addition, we can observe (Fig. 4) that during our experiments, $\mathrm{Li}$ and $\delta^{7} \mathrm{Li}$ data agree well with a simple mixing process between the initial basalt and seawater. This confirms that $\mathrm{Li}$ is a fluid-mobile element that tends to preferentially pass into the fluid phase during water/rock interaction.

In order to help in the characterization of processes controlling lithium and its isotopes in our experiments, the mineralogy of the residual solids were investigated after run completion. Transmission electron micrographs (Fig. 5) clearly show that alteration minerals are observed for experiments carried at $25^{\circ}$ and $75^{\circ} \mathrm{C}$ (alteration rings are observed in Fig. $5 \mathrm{~b}$ and $5 \mathrm{c}$ and highlighted by black arrows) and that the formation of secondary minerals is much more important for experiments carried at higher temperature $\left(200^{\circ}\right.$ and $250^{\circ} \mathrm{C}$ in Fig. $5 d$ and $5 e)$.

Moreover, infrared spectra were obtained by FTIR spectrometry for the same residual solids after run completion (at $25^{\circ}, 75^{\circ}, 200^{\circ}$ and $250^{\circ} \mathrm{C}$, Fig $6 a$ ) and the starting unaltered basalt, (Fig 6a). The infrared spectra obtained in transmission show the lines characteristic of salts contained in sea water and basalt for solids having interacted at $25^{\circ}$ and $75^{\circ} \mathrm{C}$ (Figure $6 \mathrm{~b}$ ). On the other hand, for the solids having interacted at higher temperatures $\left(200^{\circ}\right.$ and $250^{\circ} \mathrm{C}$, Figure $6 \mathrm{~b}$ ), we can notice the presence of the lines characteristic of clay minerals. The lines are rather close to that of a nontronite (smectite) for the sample having interacted at $200^{\circ} \mathrm{C}$ (line around $3565 \mathrm{~cm}^{-1}$ in the field as of elongations of the $\mathrm{OH}$ bonds) and between a nontronite and a beidellite (line centered around $3605 \mathrm{~cm}^{-1}$ in the field as of elongations of the $\mathrm{OH}$ bonds) for the sample having interacted at $250{ }^{\circ} \mathrm{C}$. In addition, X-Ray Diffraction spectra confirm the presence of smectite minerals in the solids having interacted at $200^{\circ}$ and $250^{\circ} \mathrm{C}$.

However, experiments carried by James et al. (2003) have shown that $\mathrm{Li}$ is taken up by basalt alteration phases at $150^{\circ} \mathrm{C}$ and then released at higher temperature. Uptake of Li by alteration minerals is not a one-way process. The fact that such a behavior is not observed in 
our experiments, is possibly related to the different experimental conditions explored in our study relative to those of James et al. (water/rock ratio, initial Li concentration in the solution). In particular, in our experiments, there is a large initial Li concentration gradient between the starting solution $(5 \mathrm{~mL} \times 100 \mathrm{ng} / \mathrm{g}=500 \mathrm{ng} \mathrm{Li})$ and the basalt $(0.5 \mathrm{~g} \times 7.78 \mu \mathrm{g} / \mathrm{g}=3.9 \mu \mathrm{g} \mathrm{Li})$. In spite of that, it is quite obvious that during our experiments, secondary minerals (clays) are formed during water/rock interaction and this may have played a key role on the $\mathrm{Li}$ isotopic trends documented here. The importance of $\mathrm{Li}$ isotopic fractionation during formation of $\mathrm{Li}-$ bearing secondary minerals has already been addressed in previous works (Chan and Edmond, 1988; Chan et al., 1992; 1993; 1994; James et al., 1999), which have shown that fractionation occurs when ${ }^{6} \mathrm{Li}$ is removed from the solution when clay minerals precipitate. In contrast, according to such work, the heavy $\mathrm{Li}$ isotope $\left({ }^{7} \mathrm{Li}\right)$ is not preferentially released into solution since there are no reason to expect $\mathrm{Li}$ isotope fractionation during dissolution of a fresh basalt (Pistiner and Henderson, 2003).

Therefore, in light of the above evidence, we suggest that in our experiments, the behavior of lithium (concentration and isotopic ratio) is essentially controlled by two complementary processes: $1 /$ mixing between $\mathrm{Li}$ in the initial solution (seawater, $\delta^{7} \mathrm{Li}=+31 \%$ ) and $\mathrm{Li}$ released to the solution from the basalt (Fig. 4) and 2/ uptake of lithium into secondary minerals, this process being temperature dependent.

Considering the water/rock ratio and the $\mathrm{Li}$ concentrations in seawater and basalt, we can estimate the maximum Li concentration in the solution to be about $880 \mu \mathrm{g} / \mathrm{L}$. Upon inspection of figure 2, it is obvious, however, that this maximum value is not reached in any case, which implies that another process (not simple dissolution) is controlling the release of lithium into the solution. We propose the following scenario for the observed trends in lithium and its isotopes in our experiments: as reaction time proceeds, lithium concentration in the solution increases and the $\delta^{7} \mathrm{Li}$ values flatten out. For any given temperature, two successive processes control lithium and its isotopes, as schematically illustrated on Fig. 7: first, dissolution processes are preponderant and release lithium into solution (consequently $\delta^{7} \mathrm{Li}$ sharply decreases whereas Li concentrations increase). This step is short as observed in Fig. 2. Then, during the second step, a steady state is reached between dissolution of basalt on the one hand and precipitation of alteration minerals on the other hand. The competition between dissolution and precipitation processes is likely to be the key factor controlling lithium and its isotopes in these experiments.

In addition to the different processes controlling lithium, the question of steady state is thus crucial for a correct application of the experimental results. The fact that $\delta^{7} \mathrm{Li}$ values are constant and reach a plateau at the end of each experiment is a good indication of having attained an isotopic steady state. We can, therefore, determine the $\delta^{7} \mathrm{Li}$ signature of the 
solution at steady state by averaging the constant values measured after run completion for each experiment (Fig. 2). These $\delta^{7} \mathrm{Li}$ signatures in solution determined at steady state $\left(\delta^{7} \mathrm{Li}\right.$ solution) are given in table 3.

Isotopic fractionation ( $\Delta$ solution - solid $)$ between the solution and the solid can then be calculated after run completion (when isotopic steady state is reached, Table 3). Fractionation factors range from +6.7 to $+19.4 \%$ for experiments carried at $250^{\circ}$ and $25^{\circ} \mathrm{C}$, respectively. At low temperature $\left(25^{\circ} \mathrm{C}\right)$, $\mathrm{Li}$ isotopic fractionation is much more important $\left(\Delta_{\text {solution }- \text { solid }}=+19.4 \%\right.$ ) . At higher temperatures, the fractionation factor decreases from $+12.5 \%$ at $75^{\circ} \mathrm{C}$ and $+9.5 \%$ o at $200^{\circ} \mathrm{C}$ to a value of $+6.7 \%$ at $250^{\circ} \mathrm{C}$. Altogether, these experiments confirm the strong temperature dependence of $\mathrm{Li}$ isotope exchange during water/rock interaction (Fig. 8a). In addition to this experimental approach, the water/rock interaction process may also be investigated using the modeling method reported by Magenheim et al. (1995). In this model, the initial rock is incrementally destroyed, and $\mathrm{Li}$ is partitioned into the fluid and alteration phases. The relationship of the integrated concentration of the two isotopes ${ }^{6} \mathrm{Li}$ and ${ }^{7} \mathrm{Li}$ in solution with rock/water ratio $(r / w)$ is described by the following two equations:

$$
\begin{aligned}
& r / w=-\frac{1}{K} \times \ln \left(\frac{{ }^{6} L i_{r}-K \times{ }^{6} L i_{w}}{{ }^{6} L i_{r}-K \times{ }^{6} L i_{0}}\right) \\
& r / w=-\frac{1}{\alpha K} \times \ln \left(\frac{{ }^{7} L i_{r}-\alpha K \times{ }^{7} L i_{w}}{{ }^{7} L i_{r}-\alpha K \times{ }^{7} L i_{0}}\right)
\end{aligned}
$$

${ }^{6} \mathrm{Li}_{0}$ and ${ }^{7} \mathrm{Li}_{0}$ are the initial concentrations of the two isotopes in the starting solution (seawater diluted, $\mathrm{Li}=0.1 \mathrm{mg} / \mathrm{L}$ and $\delta^{7} \mathrm{Li}=+31 \%$ ). ${ }^{6} \mathrm{Li}_{\mathrm{r}}$ and ${ }^{7} \mathrm{Li}_{\mathrm{r}}$ are the concentrations of the two isotopes in the initial rock (basalt $\mathrm{JB}-2, \mathrm{Li}=7.78 \mu \mathrm{g} / \mathrm{g}$ and $\delta^{7} \mathrm{Li}=+4.9 \%$ ). $\mathrm{K}$ is the distribution coefficient of an isotope between the solution $\left(\mathrm{Li}_{\mathrm{w}}\right)$ and the altered phase $\left(\mathrm{Li}_{\text {alt }}\right)$, and $\alpha$ is the associated isotopic fractionation $\left(\alpha=\left({ }^{7} \mathrm{Li} /{ }^{6} \mathrm{Li}\right)_{\text {liquid }} /\left({ }^{7} \mathrm{Li} /{ }^{6} \mathrm{Li}\right)_{\text {solid }}\right)$, so that:

$$
{ }^{6} L i_{a l t}=K{ }^{6} L i_{w}
$$

and

$$
{ }^{7} \mathrm{Li}_{\text {alt }}=\alpha K{ }^{7} \mathrm{Li}_{w}
$$

Since $\mathrm{K}$ and $\alpha$ are temperature dependent, different values are used for the calculations with data as compiled by Magenheim et al. (1995) and Chan et al. (2002). The empirical values 
for the parameters used are as follows: for $260^{\circ} \mathrm{C}, \mathrm{K}=0.35$ and $\alpha=0.994$; for $300^{\circ} \mathrm{C}, \mathrm{K}=$ 0.32 and $\alpha=0.995$; for $350^{\circ} \mathrm{C}, \mathrm{K}=0.27$; $\alpha=0.996$; for $400^{\circ} \mathrm{C}, \mathrm{K}=0.23$ and $\alpha=0.997$.

The $\delta^{7} \mathrm{Li}$ values calculated for liquid and solid phases following Magenheim's model are reported as a function of the water/rock ratio $(w / r)$ in Figure 9 . We note that this model is in good agreement with our experimental results. Indeed, this model takes into account a fractionation of $6 \%$ at $260^{\circ} \mathrm{C}$ between liquid and solid phases, similar to the value obtained in our experiments (i.e. $6.7 \%$ at $250^{\circ} \mathrm{C}$ ). It is also important to highlight that this isotopic fractionation value is not a function of the water/rock ratio $(w / r)$.

This feature can be investigated further by comparing our experimental constraints with $\mathrm{Li}$ isotopic fractionation and values determined either in natural environments or in other experimental studies. Most lithium fractionation values reported so far in the literature come from studies of interaction between seawater and more or less weathered basalt. The isotopic fractionation factors inferred from these studies give $\Delta$ values of $+4 \%$ at $350^{\circ} \mathrm{C},+9 \%$ o at $160^{\circ} \mathrm{C}$ and $+19 \%$ at $2^{\circ} \mathrm{C}$ (Chan and Edmond, 1988; Chan et al., 1992; 1993; 1994; James et al., 1999). These $\Delta$ values are shown in figure $8 \mathrm{a}$ as 'hydrothermal basalt alteration' for which an empirical equation was reported by James et al. (1999). Chan et al. (1994) have also shown that the isotopic composition of fluids decreases with increasing temperature. Their results clearly demonstrate that Li mobilization is a temperature-dependent process. Lithium release can begin at relatively low temperatures and increases with heating. Our experimental data are in good agreement with the relationship inferred from natural systems, namely 'hydrothermal basalt alteration' (Fig. 8a).

In figure $8 \mathrm{~b}$, isotopic fractionation determined using our experiments ( $\left.\Delta_{\text {solution - solid }}\right)$ is plotted as a function of $1000 / T$ (temperature in Kelvin, K). This graph allows us to determine the empirical relationship (Equation 5 ) between the isotopic fractionation and the reciprocal temperature $\left(R^{2}=0.93\right)$ :

$$
\Delta_{\text {solution - solid }}=\frac{7847}{T}-8.093
$$

On figure 8 are also shown the data of Wunder et al. (2006) who have worked out experimentally the $\mathrm{Li}$ isotopic fractionation between clinopyroxene and aqueous fluids at temperatures between $500^{\circ}$ and $900^{\circ} \mathrm{C}$ at $2.0 \mathrm{GPa}$. According to these authors, there is significant fractionation (about $+1 \%$ ) even at high temperatures $\left(900^{\circ} \mathrm{C}\right.$ ). Their relationship is shown in figure $8 \mathrm{~b}$, the dashed-line corresponding to an extrapolation to temperatures below $500^{\circ} \mathrm{C}$. Although the relationships derived by Wunder et al (2006) is not strictly comparable to ours owing to the widely different experimental conditions explored and solid composition 
used, the two data sets agree remarkably with each other, which considerably strengthens the use of $\mathrm{Li}$ isotopes as tracers of fluid-mineral interaction processes over a large range of P-T conditions

\subsubsection{Application to deep saline geothermal waters in volcanic island arc areas}

The $\mathrm{Li}$ isotopic compositions of deep saline geothermal waters are plotted as a function of reservoir temperatures as determined either by direct measurements or via chemical geothermometers (Fig. 10). The obtained relationship supports a temperature dependence of the $\mathrm{Li}$ isotopic signature in the geothermal reservoir showing, as a general rule, that the higher the reservoir temperature, the lower the $\mathrm{Li}$ isotopic signature of the geothermal waters. However, it is important to point out that the $\delta^{7} \mathrm{Li}$ signatures in the Lamentin and Diamant geothermal waters are very similar, despite having significantly different reservoir temperatures.

Using the experimental data ( $\Delta_{\text {solution - solid }}$ ) obtained during this study (Table 1$)$ and assuming that $\mathrm{Li}$ behaves in a manner similar in the water/rock interaction processes occurring during the experiments and within the geothermal reservoirs of Bouillante, Lamentin and Diamant, the $\delta^{7} \mathrm{Li}$ signatures of the reservoir rocks were estimated from the $\delta^{7} \mathrm{Li}$ values determined in the geothermal waters (see in Fig. 10).

According to Chan et al. (2002), the $\delta^{7} \mathrm{Li}$ value found for the rocks of the Bouillante deep reservoir (close to $\sim-2.4 \%$ ) suggests that the geothermal water is in equilibrium with rocks located in the transition zone that marks the contact between volcanic flows and basaltic dikes being a privileged region of fluid mixing. On the basis of geological and geophysical arguments (Andreieff et al., 1987), this transition zone would be located, in the Bouillante area, at a depth higher than $3 \mathrm{~km}$, or up to $5-6 \mathrm{~km}$. Lithium enrichment is accompanied by relatively low isotopic compositions, which indicate the influence of basalt-derived Li during mineralization and alteration. The high $\mathrm{Li}$ concentration analyzed for the Bouillante geothermal fluid (about $4.5 \mathrm{mg} / \mathrm{L}$ ) compared to of the experimental fluid at $250^{\circ} \mathrm{C}$ which was produced using a water/rock ratio of $10(352 \mu \mathrm{g} / \mathrm{L})$, suggests a lower water/rock ratio of about 1 to 5 in the Bouillante reservoir, keeping in mind that the initial $\mathrm{Li}$ concentration in the Bouillante reservoir rocks can be very different from that of the rock used in the laboratory experiments $(7.78 \mu \mathrm{g} / \mathrm{g})$.

The $\delta^{7} \mathrm{Li}$ value of $-2.4 \%$ determined for the reservoir rocks at $260^{\circ} \mathrm{C}$ can be also found using the model of Magenheim et al. (1995), considering a water/rock ratio (w/r) close to 4-5, a $\mathrm{Li}$ concentration of $15 \mu \mathrm{g} / \mathrm{g}$ and a $\delta^{7} \mathrm{Li}$ value of $2.7 \%$ for the initial fresh rock. This $\mathrm{Li}$ isotopic value is commonly observed in samples of unaltered basalts and basaltic andesites or lavas 
from subduction zones and island arcs $\left(\delta^{7} \mathrm{Li}\right.$ values from 1.1 to $7.6 \%$; Moriguti and Nakamura, 1998; Magna et al., 2003).

When considering the Bouillante area, such a water/rock ratio parameter can be also estimated using the relationship reported by Edmond et al. (1979):

$$
w / r=\frac{L i_{F R}}{L i_{G F}-L i_{D S W}}
$$

where $\mathrm{Li}_{\mathrm{FR}}$ is the $\mathrm{Li}$ concentration in the fresh rock, $\mathrm{Li}_{\mathrm{GF}}$ is the $\mathrm{Li}$ concentration in the geothermal fluid and $\mathrm{Li}_{\mathrm{IF}}$ is the $\mathrm{Li}$ concentration in the diluted seawater (i.e. initial fluid).

For different $\mathrm{Li}$ concentrations in the fresh rock ( $\mathrm{Li}_{\mathrm{FR}}$ ranging from 5, 10, 15 and $25 \mu \mathrm{g} / \mathrm{g}$ ), we obtain the following values for the water/rock ratio $(\mathrm{w} / \mathrm{r}): 1.2,2.4,3.6$ and 4.8 respectively, which are in a good agreement with estimates based on our experimental constraints $(\mathrm{w} / \mathrm{r}$ from 1 to 5$)$.

Lastly, the water/rock ratio at Bouillante $(w / r)$ can also be estimated using the relationship of Albarède et al. (1981) for $\mathrm{Sr}$ isotopes concerning hydrothermal alteration of the oceanic crust:

$$
w / r=\frac{\left(\frac{{ }^{87} S r}{{ }^{86} S r}\right)_{G F}-\left(\frac{{ }^{87} S r}{{ }^{86} S r}\right)_{F R}}{\left(\frac{{ }^{87} S r}{{ }^{86} S r}\right)_{D S W}-\left(\frac{{ }^{87} S r}{{ }^{86} S r}\right)_{G F}} \times \frac{S r_{F R}}{S r_{D S W}}
$$

where $\left({ }^{87} \mathrm{Sr} /{ }^{86} \mathrm{Sr}\right)_{\mathrm{GF}}=0.70496,\left({ }^{87} \mathrm{Sr} /{ }^{86} \mathrm{Sr}\right)_{\mathrm{FR}}=0.7041$ and $\left({ }^{87} \mathrm{Sr} /{ }^{86} \mathrm{Sr}\right)_{\mathrm{DSW}}=0.709$ are the $\mathrm{Sr}$ isotopic ratios of geothermal fluid, fresh rock and seawater, respectively. $\mathrm{And}_{\mathrm{Sr}} \mathrm{FR}_{\mathrm{F}}$ and $\mathrm{Sr}_{\mathrm{DSW}}$ are the $\mathrm{Sr}$ concentrations for fresh rock and diluted seawater, respectively (we assume here that the dilution of seawater $(60 \%)$ by fresh water $(40 \%)$ does not affect the $\mathrm{Sr}$ isotopic ratio). After calculation, we obtain a $\mathrm{w} / \mathrm{r}$ ratio value close to 4.1 for $\mathrm{Sr}_{\mathrm{FR}}=100 \mu \mathrm{g} / \mathrm{g}$ and $\mathrm{w} / \mathrm{r}=8.2 \mathrm{for}$ $\mathrm{Sr}_{\mathrm{FR}}=200 \mu \mathrm{g} / \mathrm{g}$.

It thus appears that both $\mathrm{Li}$ and $\mathrm{Sr}$-based estimates converge towards a water/rock ratio $(\mathrm{w} / \mathrm{r})$ value around 4-5, assuming that $\mathrm{Li}$ and $\mathrm{Sr}$ concentrations in the fresh rock are close to 15-20 and $100 \mu \mathrm{g} / \mathrm{g}$, respectively, which are values commonly observed in subduction zone and island arc basalts, enriched in Li relative to the mantle (5-6 $\mu \mathrm{g} / \mathrm{g}$ in normal MORB; Tomascak, 2004).

For the Diamant area, the same value of $\delta^{7} \mathrm{Li}$ as that of Bouillante (close to $\sim-2.4 \%$ ) is found for the reservoir rocks. Given that the $\mathrm{Na} / \mathrm{Li}$ geothermometer suggests that the geothermal 
fluid is partially in equilibrium with sedimentary rocks, contrary to the Bouillante area, and according to the literature data (Tomascak, 2004; Chan et al., 2006, Millot et al. 2007), this negative value could reflect the presence of sedimentary rocks in the deep reservoir.

In the Lamentin plain, the geothermal reservoir is relatively shallow and is constituted of volcano-sedimentary rocks. The $\mathrm{Na} / \mathrm{Li}$ geothermometer, which suggests that the geothermal fluid is partially in equilibrium with sedimentary rocks, is in a good agreement with this reservoir composition. The $\delta^{7} \mathrm{Li}$ values estimated for the reservoir rocks (close to -5 and $-6 \%$; Fig. 10) are low compared to literature data (Tomascak, 2004). However, a $\delta^{7} \mathrm{Li}$ value of $4.7 \%$ was analyzed by BRGM in an altered white lava collected from the borehole Carrère at a depth of $414 \mathrm{~m}$. As shown by Sturchio and Chan (2003) for the Yellowstone system, hydrothermal alteration products of volcanic rocks have also extremely low $\delta^{7} \mathrm{Li}$ value ($4.8 \%$ ). On the other hand, it is possible that the $\mathrm{Li}$ isotopic fractionation equation determined for basalt in this study is less well adapted for the volcano-sedimentary rocks which constitute this reservoir, where the sedimentary rocks are abundant.

Lithium concentrations and $\delta^{7} \mathrm{Li}$ values are, therefore, not only a useful tool to estimate the temperature of geothermal reservoirs but can also be used to determine the nature (and sometimes the depth) of the reservoir rocks. Additional water/rock interaction experiments (fresh water/basalt, seawater and fresh water/andesite, etc.) similar to those reported here would enable us to complete this study and add to our understanding of Li behavior in island arc geothermal systems.

\section{CONCLUSIONS}

The present work has made it possible to better characterize the behavior of $\mathrm{Li}$ and its isotopes in geothermal systems located in volcanic island arc areas such as those in Guadeloupe and Martinique. The main results of this study are:

- The deep geothermal waters collected from wells and thermal springs indicate that $\mathrm{Li}$ isotopic signatures are very homogeneous for a given site. This confirms the geochemical homogeneity of the geothermal systems under consideration and is a good argument for using the Li/Na geothermometer to calculate reservoir temperature. Moreover, it is important to highlight that the Bouillante geothermal reservoir is the most homogeneous from a $\mathrm{Li}$ isotope point of view, with a mean value of $\delta^{7} \mathrm{Li}=+4.4 \% \pm 0.4(2 \sigma, \mathrm{n}=8)$ without any short term temporal variation (1999-2002).

- The $\mathrm{Li}$ isotopic signatures of each of these geothermal systems are also very different, as a result of both highly variable temperatures of water/rock interaction $\left(90-120^{\circ} \mathrm{C}\right.$ for the 
Lamentin plain, $180^{\circ} \mathrm{C}$ for the Diamant area and $250-260^{\circ} \mathrm{C}$ for the Bouillante geothermal fields), but also of lithological differences of the reservoir rocks.

- Li isotopic tracing confirms a process of mixing between deep geothermal fluid and seawater for submarine thermal springs.

- Experiments of seawater/basalt interaction were carried out at different temperatures and the results confirm the temperature dependence of $\mathrm{Li}$ isotope fractionation, ranging from +19.4 to $+6.7 \%$ ( $\Delta$ solution - solid $)$ between $25^{\circ}$ and $250^{\circ} \mathrm{C}$, in agreement with available field and experimental data. We suggest that, in our experiments, lithium and its isotopes are controlled by two complementary processes: 1/ mixing between lithium in seawater and lithium released in solution from the basalt $2 /$ uptake of lithium into secondary minerals.

- These experimental results were applied to the saline geothermal waters collected from the Bouillante and Lamentin wells, and from the Diamant thermal spring. Based on literature data and some assumptions, the results suggest that the Bouillante geothermal water is in equilibrium with a reservoir composed of rocks located at the transition zone between volcanic flows and basaltic dikes and is a privileged region of fluid mixing. This zone would be situated at a depth higher than $3 \mathrm{~km}$, or even around $5-6 \mathrm{~km}$. In the Lamentin and Diamant areas, the $\mathrm{Na} / \mathrm{Li}$ geothermometer and the $\mathrm{Li}$ isotopic signature suggest that the geothermal fluid is partially in equilibrium with reservoir sedimentary rocks.

Therefore, we conclude that lithium isotopic systematics is a powerful tool for the characterization of temperature and to infer the origin of the waters and the nature of the reservoir rocks. 


\section{Acknowledgements}

This work was funded by a BRGM-ADEME joint research partnership through the GHEDOM project (Géothermie Haute Enthalpie dans les Départements d'Outre-Mer). We thank M. Brach for his help collecting samples, BRGM Offices (SGR/Guadeloupe and SGR/Martinique), CFG Services and Geothermie Bouillante for their local help. The work benefited from the collaboration of F. Delorme, V. Jean-Prost and C. Bény (BRGM, Mineral characterization unit), who provided TEM, XRD and FTIR spectra analyses. We would also like to acknowledge A. Genter and Ph. Négrel for fruitful discussions. L.H. Chan is acknowledged for providing helpful comments in an earlier version of the manuscript. Finally, we also would like to thank Aimee Hegan for comments and English corrections. This is BRGM contribution $n^{\circ} X X X X$. 


\section{References}

Albarède F., Michard A., Minster J.F. and Michard G. (1981) ${ }^{87} \mathrm{Sr} /{ }^{86} \mathrm{Sr}$ ratios in hydrothermal waters and deposits from the East Pacific Rise at $21^{\circ} \mathrm{N}$. Earth and Planetary Science Letters, 55, 229-236.

Andreieff P., Bouysse Ph. and Westercamp D. (1987) Géologie de l'arc insulaire des Petites Antilles, et évolution géodynamique de l'Est-Caraïbe. Thèse de Doctorat d'Etat ès Sciences, Université de Bordeaux 1, 360 p.

Arnorsson S. and Gunnlaugsson E. (1983) The chemistry of geothermal waters in Iceland. III. Chemical geothermometry in geothermal investigations. Geochim. Cosmochim. Acta, 47, 567-577.

Carignan J., Vigier N. and Millot R. (2007) Three secondary reference materials for $\mathrm{Li}$ isotopic measurements: ${ }^{7} \mathrm{Li}-\mathrm{N},{ }^{6} \mathrm{Li}-\mathrm{N}$ and LiCl-N. Geostandards and Geoanalytical Research, 31, 7-12.

Chan L.H. and Edmond J.M. (1988) Variation of lithium isotope composition in the marine environment: A preliminary report. Geochimica et Cosmochimica Acta, 52, 1711-1717.

Chan L.H., Edmond J.M., Thompson G. and Gillis K. (1992) Lithium isotopic composition of submarine basalts: implications for the lithium cycle in the oceans. Earth and Planetary Science Letters, 108, 151-160.

Chan L.H., Edmond J.M. and Thompson G. (1993) A lithium isotope study of hot springs and metabasalts from mid-ocean ridge hydrothermal systems. Journal of Geophysical Research, 98, 9653-9659.

Chan L.H., Gieskes J.M., You C.F. and Edmond J.M. (1994) Lithium isotope geochemistry of sediments and hydrothermal fluids of the Guaymas Basin, Gulf of California. Geochimica et Cosmochimica Acta, 58, 4443-4454.

Chan L. H., Alt J.C. and Teagle D.A.H. (2002) Lithium and lithium isotope profiles through the upper oceanic crust: a study of seawater-basalt exchange at ODP Sites 504B and 896A. Earth and Planetary Science Letters, 201, 187-201.

Coplen T.B., Hopple J.A., Böhlke J.K., Peiser H.S., Rieder S.E., Krouse H.R., Rosman K.J.R., Ding T., Vocke R.D.Jr., Révész K.M., Lamberty A., Taylor P. and De Bièvre P. (2002) Compilation of minimum and maximum isotope ratios of selected elements in naturally occurring terrestrial materials and reagents. U.S. Geological Survey, WaterResources Investigations, Report 01-4222.

Correia H., Sigurdsson O., Sanjuan B., Tulinius H. and Lasne E. (2000) Stimulation test of a high-enthalpy geothermal well by cold water injection. Geothermal Resources Council Transactions, Davis, California, 24, 129-136. 
Edmond J.M., Measures C., Mc Duff R.E., Chan L.H., Collier R. and Grant B. (1979) Ridge crest hydrothermal activity and the balances of the major and minor elements in the Ocean: the Galapagos data. Earth and Planetary Sci. Lett., 46, 1-18.

Fabriol H., Bitri A., Bourgeois B., Debeglia N., Genter A., Guennoc P., Jousset P., Miehe J.M., Roig J.Y., Thinon I., Traineau H., Sanjuan B. and Truffert C. (2005) Geophysical methods applied to the assessment of the Bouillante geothermal field (Guadeloupe, French West Indies). Proceedings World Geothermal Congress 2005, Antalya, Turkey, 24-29 April 2005.

Flesch G.D., Anderson A.R. and Svec H.J. (1973) A secondary isotopic standard for ${ }^{6} \mathrm{Li} /{ }^{7} \mathrm{Li}$ determinations. International Journal of Mass Spectrometry and Ion Physics, 12, 265-272.

Fouillac C. and Michard G. (1981) Sodium/lithium ratio in water applied to geothermometry of geothermal reservoirs. Geothermics, 10, 55-70.

Fournier R.O. and Rowe J.J. (1966) Estimation of underground temperatures from the silica content of water from hot springs and wet-steam wells. American Journal of Science, 264, 685-697.

Fournier R.O. and Truesdell A.H. (1973) An empirical Na-K-Ca geothermometer for natural waters. Geochimica et Cosmochimica Acta, 37, 1255-1275.

Fournier R.O. and Potter R.W. (1979) Magnesium correction to the Na-K-Ca chemical geothermometer. Geochim. Cosmochim. Acta, 43, 1543-1550.

Fournier R.O. (1979) A revised equation for the Na/K geothermometer. Geotherm. Res. Counc. Trans., 3, 221-224.

Genter A., Traineau H., Degouy M., Correia H., Mas A., Patrier P., Roig J.Y. and Sanjuan B. (2002) Preliminary geological results of recent exploratory drillings in a geothermal fractured reservoir at Lamentin (French West Indies, Martinique), Proceedings, $27^{\text {th }}$ Workshop on Geothermal Reservoir Engineering, Stanford University, Stanford, CA, 241247.

Giggenbach W.F. (1988) Geothermal solute equilibria. Derivation of $\mathrm{Na}-\mathrm{K}-\mathrm{Mg}-\mathrm{Ca}$ geoindicators. Geochim. Cosmochim. Acta, 52, 2749-2765.

James R.H., Rudnicki M.D. and Palmer M.R. (1999) The alkali element and boron geochemistry of the Escanaba Trough sediment-hosted hydrothermal system. Earth and Planetary Science Letters, 171, 157-169.

James R.H. and Palmer M.R. (2000) The lithium isotope composition of international rock standards. Chemical Geology, 166, 319-326.

James R.H., Allen D.E. and Seyfried W.E. (2003) An experimental study of alteration of oceanic crust and terrigenous sediments at moderate temperatures (51 to $350^{\circ} \mathrm{C}$ ): Insights as to chemical processes in near-shore ridge-flank hydrothermal systems. Geochimica et Cosmochimica Acta, 67, 681-691. 
Kharaka Y.K., Lico M.S. and Lax L.M. (1982) Chemical geothermometers applied to formation waters, Gulf of Mexico and California basins. Am. Assoc. Petrol. Geol. Bull., 66, 588.

Kharaka Y.K. and Mariner R.H. (1989) Chemical geothermometers and their application to formation waters from sedimentary basins. In: Naeser, N.D. and McCulloch, T.H. (eds), Thermal history of sedimentary basins: methods and case histories. Springer-Verlag, New York, 99-117.

Magenheim A.J., Spivack A.J., Alt J.C., Bayhurst G., Chan L.H., Zuleger E. and Gieskes J.M. (1995) Borehole fluid chemistry in hole 504B, leg 137: formation water or in-situ reaction? Proceedings of the Ocean Drilling Program, Scientific Results, vol. 137/140, 141-152.

Magna T., Wiechert U., Grove T.L., Halliday A.N. (2003) Lithium isotope composition of arc volcanics from the Mt Shasta region, N California. Geochim. Cosmochim. Acta, 67, A267.

Mas A., Guisseau D., Patrier P., Beaufort D., Genter A., Sanjuan B and Girard J.P. (2006) Clay minerals related to the hydrothermal activity of the Bouillante geothermal field (Guadeloupe). J. Volcanology and Geothermal Research, 158, 380-400.

Michard G. (1979) Géothermomètres chimiques. Bull. du BRGM (2 ${ }^{\text {ème }}$ série), Section III, 2, 183-189.

Michard G. (1990) Behaviour of major elements and some trace elements ( $\mathrm{Li}, \mathrm{Rb}, \mathrm{Cs}, \mathrm{Sr}, \mathrm{Fe}$, Mn, W, F) in deep hot waters from granitic areas. Chemical Geology, 89, 117-134.

Millot R., Guerrot C. and Vigier N. (2004) Accurate and high precision measurement of lithium isotopes in two reference materials by MC-ICP-MS. Geostandards and Geoanalytical Research, 28, 53-159.

Millot R, Negrel Ph, Petelet-Giraud E (2007) Multi-isotopic ( $\mathrm{Li}, \mathrm{B}, \mathrm{Sr}$, Nd) approach for geothermal reservoir characterization in the Limagne Basin (Massif Central, France) Applied Geochemistry, 22, 2307-2325

Mizutani Y. and Rafter T.A. (1969) Oxygen isotopic composition of sulphates, 3. Oxygen isotopic fractionation in the bisulphate ion-water system. N. Zealand J. Sci., 12, p. 54-59.

Moriguti T. and Nakamura E. (1998) Across-arc variation of $\mathrm{Li}$ isotopes in lavas and implications for crust/mantle recycling at subduction zones. Earth Planet. Sci. Lett., 163, 167-174.

Pistiner J.S. and Henderson G.M. (2003) Lithium isotope fractionation during continental weathering processes. Earth and Planetary Science Letters, 214, 327-339.

Sanjuan B. and Brach M. (1997) Etude hydrogéochimique du champ géothermique de Bouillante (Guadeloupe). Report BRGM R39880, 84 p.

Sanjuan B. (2001) Champ géothermique de Bouillante (Guadeloupe): synthèse des travaux réalisés en géochimie avant 1999. Final report BRGM/RC-51672-FR, 54 p. 
Sanjuan B., Lasne E. and Brach M. (2001) Bouillante geothermal fluid: mixing and water/rock interaction processes at $250^{\circ} \mathrm{C}$. Proceedings, $10^{\text {th }}$ Water-Rock Interaction (WRI-10), Cagliari, Italy, June 10-15, vol. 2, 911-914.

Sanjuan B., Genter A., Correia H., Girard J.P., Roig J.Y. and Brach M. (2002a) Travaux scientifiques associés à la réalisation des trois puits d'exploration géothermique dans la plaine du Lamentin (Martinique). Convention BRGM-ADEME $\mathrm{n}^{\circ}$ 99.05.026. Final report BRGM-51671-FR, 253 p.

Sanjuan B., Traineau H., Genter A., Correia H., Brach M. and Degouy M. (2002b) Geochemical investigations during a new geothermal exploration phase in the Lamentin plain (Martinique, French West Indies), Proceedings, 27 $7^{\text {th }}$ Workshop on Geothermal Reservoir Engineering, Stanford University, Stanford, CA, 198-205.

Sanjuan B., Brach M. and Foucher J.C. (2003) Réévaluation du potentiel géothermique dans les régions de Morne Rouge - Montagne Pelée et du Diamant (Martinique) : étude géochimique. Final report BRGM/RP-52547-FR, 80 p.

Sanjuan B., Millot R., Brach M., Foucher J.C., Roig J.Y. and Baltassat J.M. (2005) Geothermal exploration in the Mount Pelée volcano-Morne Rouge and Diamant areas (Martinique, West French Indies): Geochemical data, in World Geothermal Congress 2005 - Antalya - Turkey - 24-29/04/2005.

Scaillet B., Pichavant M., Roux J., Humbert G. and Lefevre A. (1992) Improvements of the Shaw membrane technique for measurement and control of $\mathrm{fH}_{2}$ at high temperatures and pressures. American Mineralogist, 77, 647-655.

Sturchio N.C. and Chan L.H. (2003) Lithium isotope geochemistry of the Yellowstone hydrothermal system. Special Publication, Society of Economic Geologists (U. S.), 10, 171-180.

Tomascak P.B. (2004) Developments in the Understanding and Application of Lithium Isotopes in the Earth and Planetary Sciences. In Reviews in Mineralogy \& Geochemistry, 55, 153-195.

Traineau H., Sanjuan B., Beaufort D., Brach M., Castaing C., Correia H., Genter A. and Herbrich B. (1997) The Bouillante geothermal field (F.W.I.) revisited: new data on the fractured geothermal reservoir in light of a future stimulation experiment in a low productive well. In: Proceedings, Twenty-Second Workshop on Geothermal Reservoir Engineering, Stanford University, Stanford, California, January 27-29, 1997, SGP-TR-155, 97-104.

Wunder B., Meixner A., Romer R.L. and Heinrich W. (2006) Temperature-dependent isotopic fractionation of lithium between clinopyroxene and high-pressure hydrous fluids. Contrib. Mineral Petrol., 151, 112-120. 


\section{Figure captions}

\section{Figure 1}

Map of sampling sites in the Bouillante area (Guadeloupe), in the Lamentin and Diamant areas (Martinique). Detailed information concerning the location of the sampling sites can be found in Traineau et al. (1997), Sanjuan and Brach (1997) and Sanjuan et al. (2001) for the Bouillante area, and in Sanjuan et al. (2002a, b) and Sanjuan et al. (2003; 2005) for Martinique (Lamentin plain and Diamant areas).

\section{Figure 2}

Graphs showing the evolution with time of the solution for lithium isotopic composition in red $\left(\delta^{7} \mathrm{Li}, \%\right)$ and $\mathrm{Li}$ concentration in blue $(\mathrm{Li}, \mu \mathrm{g} / \mathrm{L})$ during experiments at $25^{\circ}, 75^{\circ}, 200^{\circ}$ and $250^{\circ} \mathrm{C}$. Lithium isotopic composition determined at steady state $\left(\delta^{7} \mathrm{Li}\right.$ equ, i.e.: equilibrium: equ) in the solution corresponds to the average value reached at isotopic steady state and is calculated by averaging the constant values at the end of each run. At $200^{\circ} \mathrm{C}$, red circles and red squares correspond, respectively, to experiments carried with gold capsules in an autoclave and with a Teflon ${ }^{\circledR}$ PTFE bomb placed in a screw-top stainless-steel container in an oven.

\section{Figure 3}

Lithium isotopic compositions ( $\delta^{7} \mathrm{Li}, \%$ ) in waters from the Bouillante (red) and Lamentin (green) geothermal fields plotted as a function of the $\mathrm{Li} / \mathrm{Cl}$ ratio. The temperature of the deep geothermal reservoir was estimated by geothermometry to be about $90-120^{\circ} \mathrm{C}$ and 250 $260^{\circ} \mathrm{C}$ for the Lamentin and Bouillante areas, respectively.

\section{Figure 4}

Graphs showing the lithium isotopic composition $\left(\delta^{7} \mathrm{Li}, \%\right.$ ) as a function of $1 / \mathrm{Li}\left(\mathrm{ppb}^{-1}\right)$ in the liquid fraction during experiments at $25^{\circ}, 75^{\circ}, 200^{\circ}$ and $250^{\circ} \mathrm{C}$.

\section{Figure 5}

Transmission electron micrographs of the starting solid material (basalt JB-2) and the different solid run products (powdered basalt after interaction) at the end of each experiment $\left(25^{\circ}, 75^{\circ}, 200^{\circ}\right.$ and $250^{\circ} \mathrm{C}$.). The black arrows show the formation of clay minerals. The white arrows show the presence of residual salts after the evaporation of remaining seawater.

\section{Figure 6}


(a) Infrared spectra obtained by FTIR spectrometry for residual solids after run completion (at $25^{\circ}, 75^{\circ}, 200^{\circ}$ and $250^{\circ} \mathrm{C}$ ) and the initial materials (seawater and basalt).

(b) Infrared spectra for experiments after correction of remaining seawater and initial basalt.

\section{Figure 7}

Schematic graph showing the evolution of $\delta^{7} \mathrm{Li}$ values and lithium concentrations in liquid as a function of time.

\section{Figure 8}

(a) Lithium isotopic fractionation between solution and solid ( $\left.\Delta_{\text {solution - solid }}\right)$ determined in our experiments vs. the interaction temperature (red circles and red curve). The blue curve corresponds to isotopic fractionation factors inferred from studies of altered basalt and hydrothermal solutions that give $\Delta$ values of $+4 \%$ at $350^{\circ} \mathrm{C},+9 \%$ at $160^{\circ} \mathrm{C}$ and $+19 \%$ at $2^{\circ} \mathrm{C}$ (Chan and Edmond, 1988; Chan et al., 1992; Chan et al., 1993; Chan et al., 1994; James et al., 1999).

(b) Lithium isotopic fractionation between solution and solid ( $\Delta$ solution - solid $)$ calculated in our experiments (red circles) vs. the inverse of the temperature of interaction (1000/T, K). The red line represents the correlation obtained in our experiments. The blue line corresponds to isotopic fractionation inferred from hydrothermal basalt interaction. The grey line represents the experimental relationship determined by Wunder et al. (2006), between $500^{\circ}$ and $900^{\circ} \mathrm{C}$, and the dashed grey line is an extrapolation below $500^{\circ} \mathrm{C}$.

\section{Figure 9}

Lithium isotopic composition ( $\delta^{7} \mathrm{Li}, \%$ ) for water and solid (alteration products) phases as a function of water/rock ratio (w/r) following Magenheim's model (Magenheim et al., 1995) for temperatures of interaction ranging between $260^{\circ}$ and $400^{\circ} \mathrm{C}$. The empirical values for the parameters used are as follows: for $260^{\circ} \mathrm{C}, \mathrm{K}=0.35$ and $\alpha=0.994$; for $300^{\circ} \mathrm{C}, \mathrm{K}=0.32$ and $\alpha$ $=0.995$; for $350^{\circ} \mathrm{C}, \mathrm{K}=0.27$; $\alpha=0.996$; for $400^{\circ} \mathrm{C}, \mathrm{K}=0.23$ and $\alpha=0.997$.

\section{Figure 10}

Lithium isotopic compositions $\left(\delta^{7} \mathrm{Li}, \%\right)$ in well fluids from the Lamentin, Diamant and Bouillante geothermal fields plotted as a function of the temperature of the reservoir determined either by direct measurements (Bouillante and Lamentin wells) or chemical geothermometers (Diamant, Bouillante and Lamentin wells). Parametric curves correspond to different values of $\delta^{7} \mathrm{Li}$ in reservoir rocks (from -2 to $-8 \%$ ) assuming the temperature 
dependence of $\mathrm{Li}$ isotopic fractionation obtained in the present work by experiments (Table $3)$. 


\section{Table captions}

\section{Table 1}

Seawater/basalt interaction at different temperatures. Lithium concentration $(\mu \mathrm{g} / \mathrm{L})$ and isotopic composition $\left(\delta^{7} \mathrm{Li}, \%\right)$ values in the solution are grouped according to the experimental method used and run duration for each experiment carried out at $25^{\circ}, 75^{\circ}, 200^{\circ}$ and $250^{\circ} \mathrm{C}$. The initial solution is a seawater solution diluted to $60 \%$ (with ultrapure $\mathrm{H}_{2} \mathrm{O}$ Milli$\mathrm{Q}^{\circledR}$ ). It has a $\mathrm{Li}$ concentration of $\mathrm{Li}=100 \mu \mathrm{g} / \mathrm{L}$ and a $\mathrm{Li}$ isotopic composition of $\delta^{7} \mathrm{Li}=+31.0 \%$. Sample aliquots $(300 \mu \mathrm{l})$ were filtered and weighed. During mass spectrometry analysis, the ${ }^{7} \mathrm{Li}$ beam intensity of the sample was compared to that of the L-SVEC standards (standard bracketing measurement), enabling us to determine the Li concentration of the solution. We estimate a typical error of $\pm 10 \%$ for this determination based on replicate measurements of seawater samples. Replicate analyses were performed for experiments carried at $250^{\circ} \mathrm{C}$ and are in good agreement within the range of $\pm 0.5 \%$ o $(2 \sigma)$.

\section{Table 2}

Major cations and anions, lithium concentrations and $\mathrm{Li}$ isotopic compositions of water samples from the Bouillante, Lamentin and Diamant geothermal fields. The temperatures given are those measured during sampling, whereas the temperatures within the geothermal reservoirs are around $250-260^{\circ} \mathrm{C}, 90-120^{\circ} \mathrm{C}$ and $180^{\circ} \mathrm{C}$, respectively, for Bouillante, Lamentin and Diamant. Sample BO-4-00-220A was collected in the weir box, BO-4-00-222B after the phase separator, and $\mathrm{BO}-4-00-222 \mathrm{C}$ is a sample of condensate after separated steam.

\section{Table 3}

$\mathrm{Li}$ isotopic composition determined at steady state in the solution $\left(\delta^{7} \mathrm{Li}\right.$ solution $)$ and in the solid phase $\left(\delta^{7} \mathrm{Li}\right.$ basalt $)$ for seawater/basalt interaction experiments carried out at $25^{\circ}, 75^{\circ}, 200^{\circ}$ and $250^{\circ} \mathrm{C}$. The uncertainty is the standard deviation $(2 \sigma)$ of the $\delta^{7} \mathrm{Li}$ values at run completion for each experiment. The fractionation ( $\Delta$ solution - solid) is the difference in Li isotopic composition between the solution and the basalt for each experiment at steady state. 
Figure 1

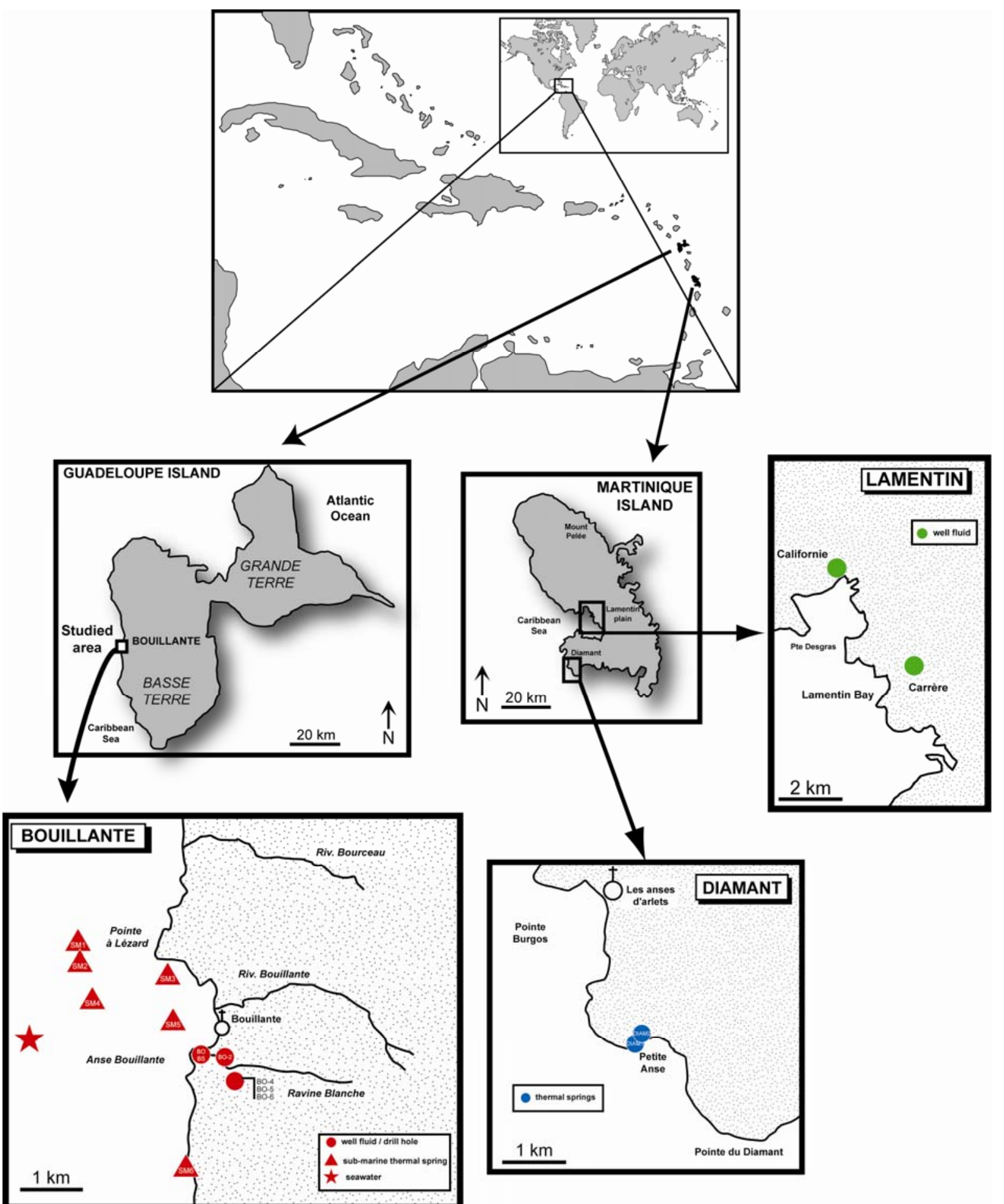


Figure 2

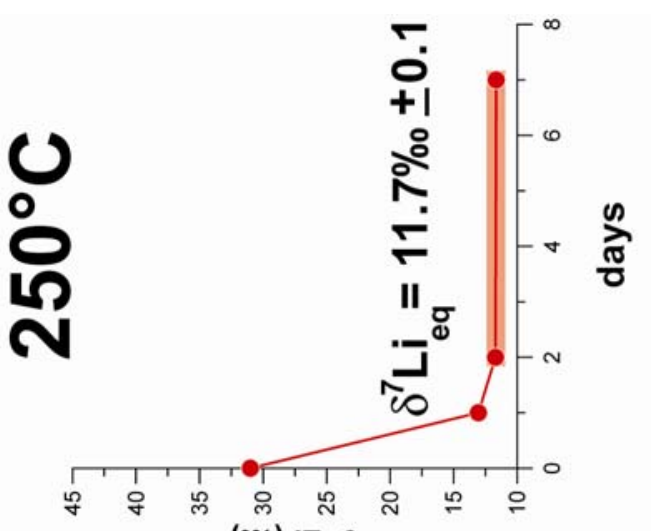

(0\%) $! 7_{L} \mathrm{~s}$
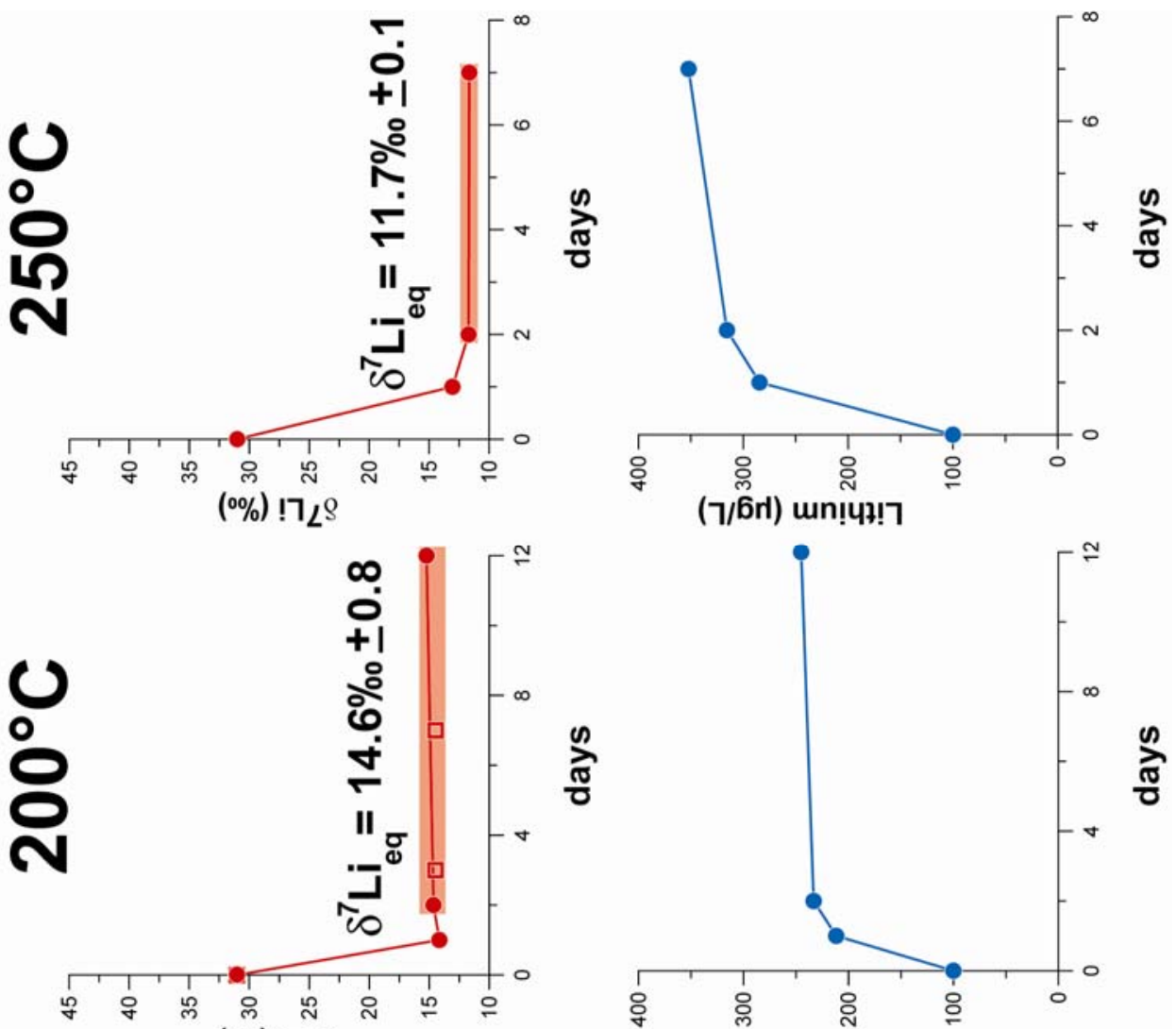

(0\%) $! 7_{L} \mathrm{~s}$
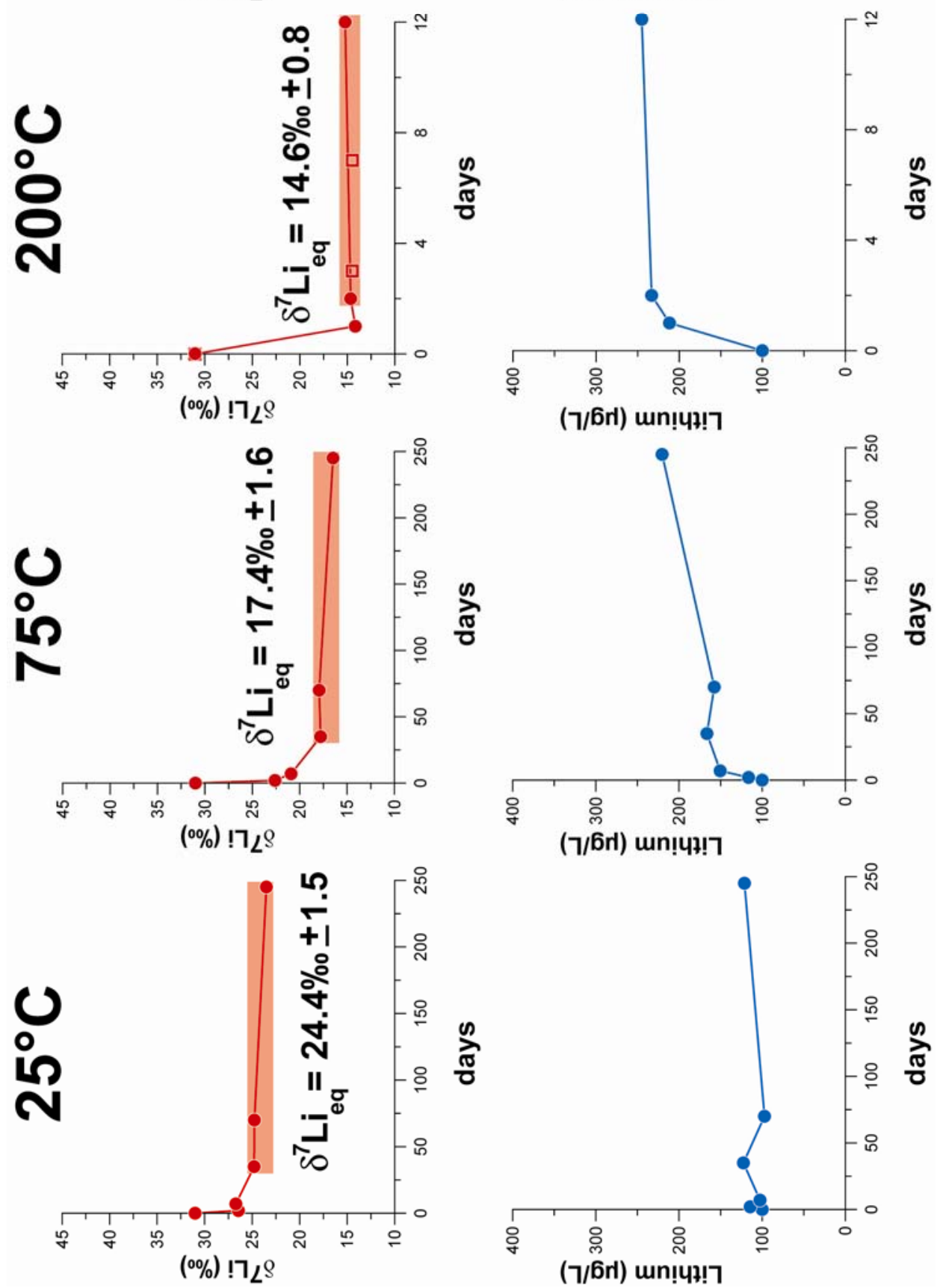


\section{Figure 3}

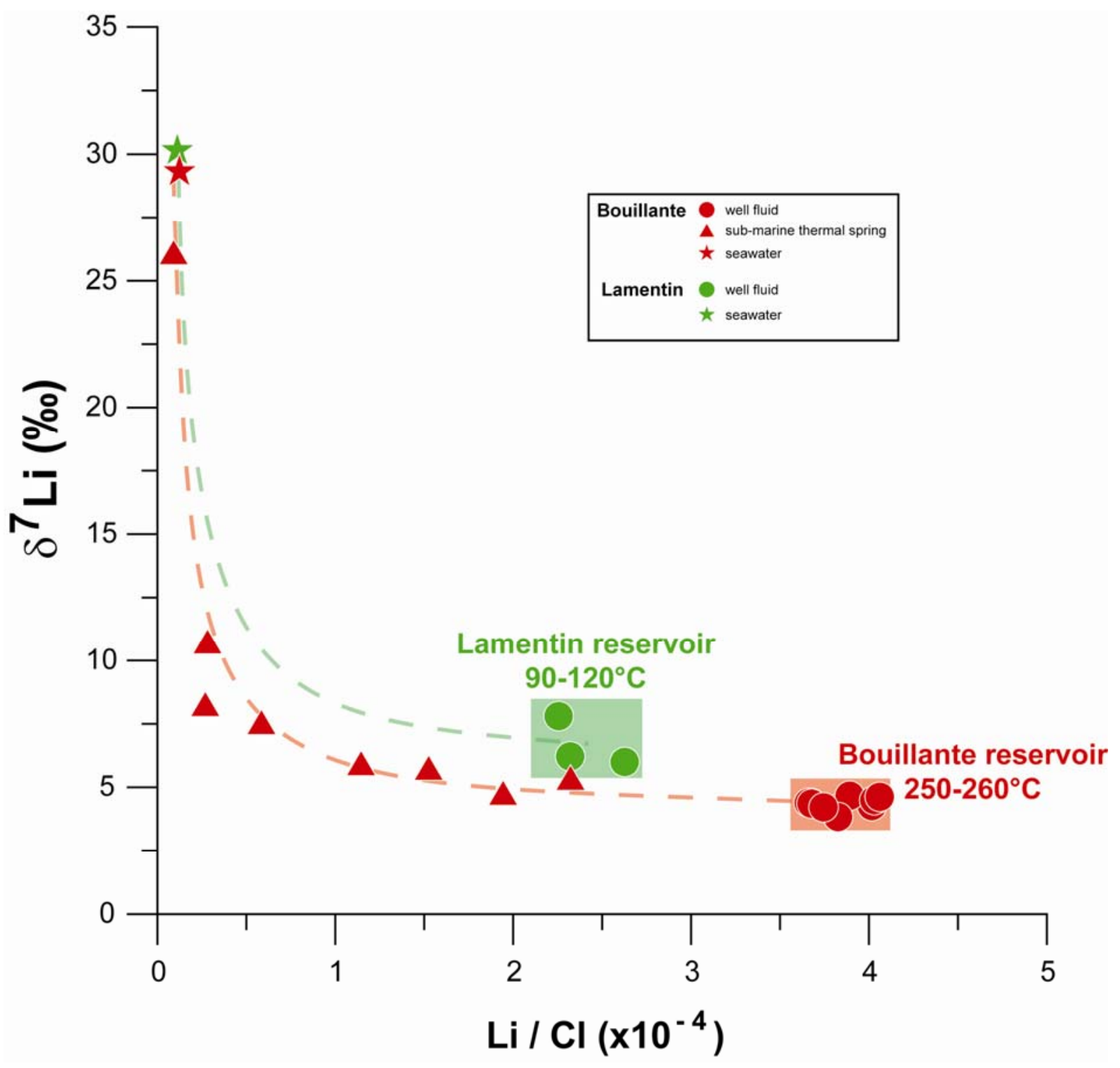


Figure 4

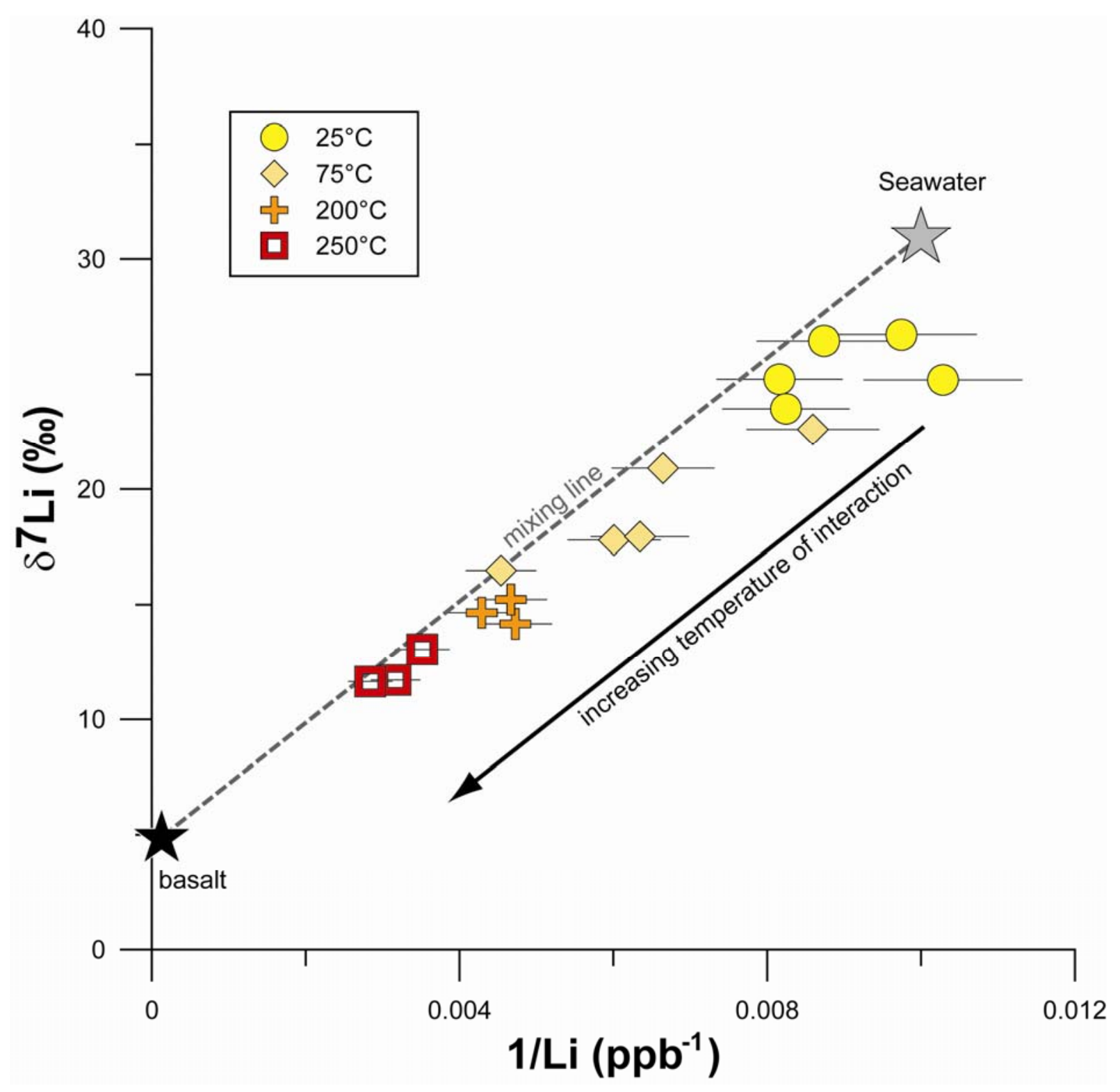


Figure 5
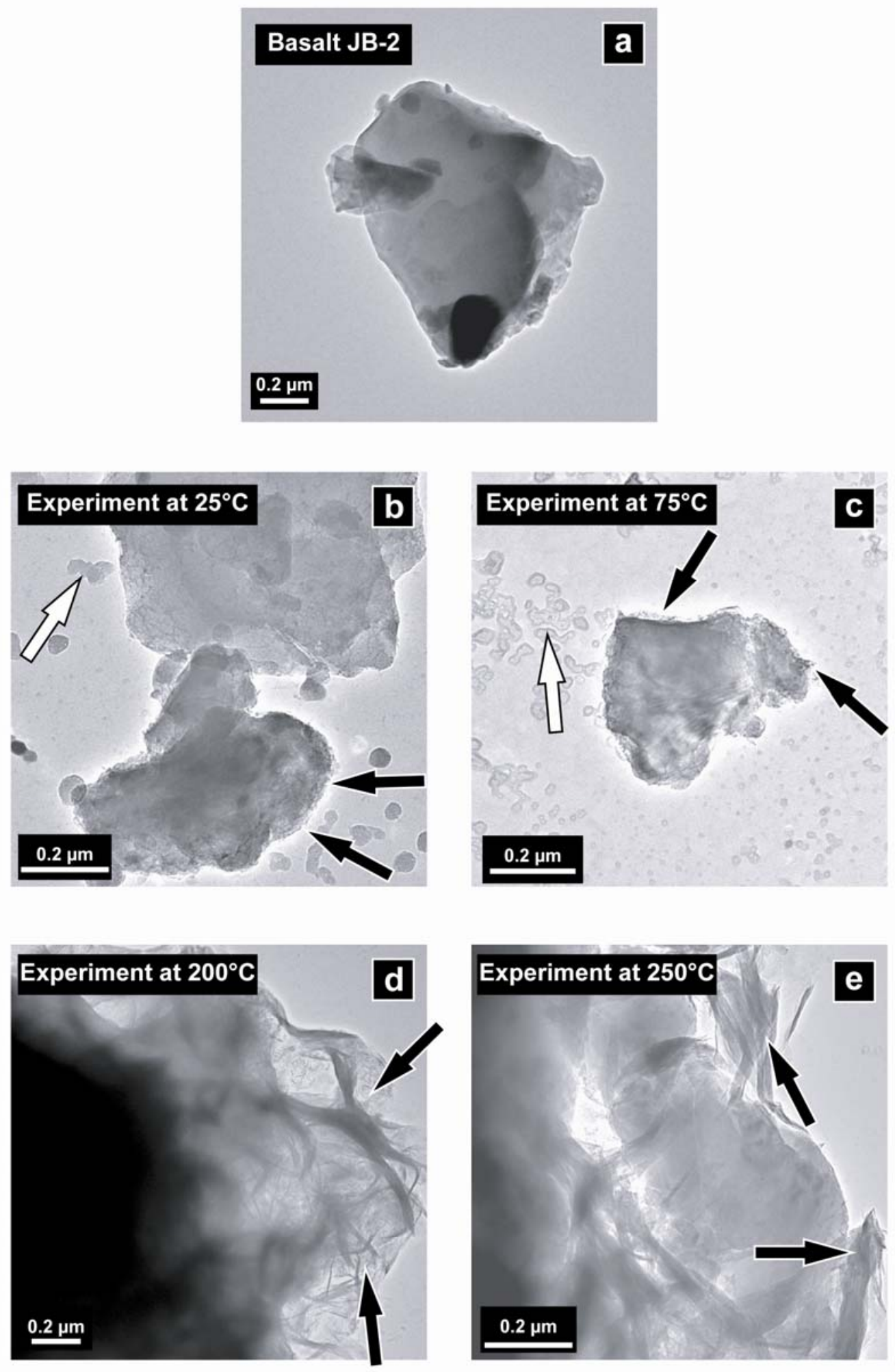


\section{Figure 6}
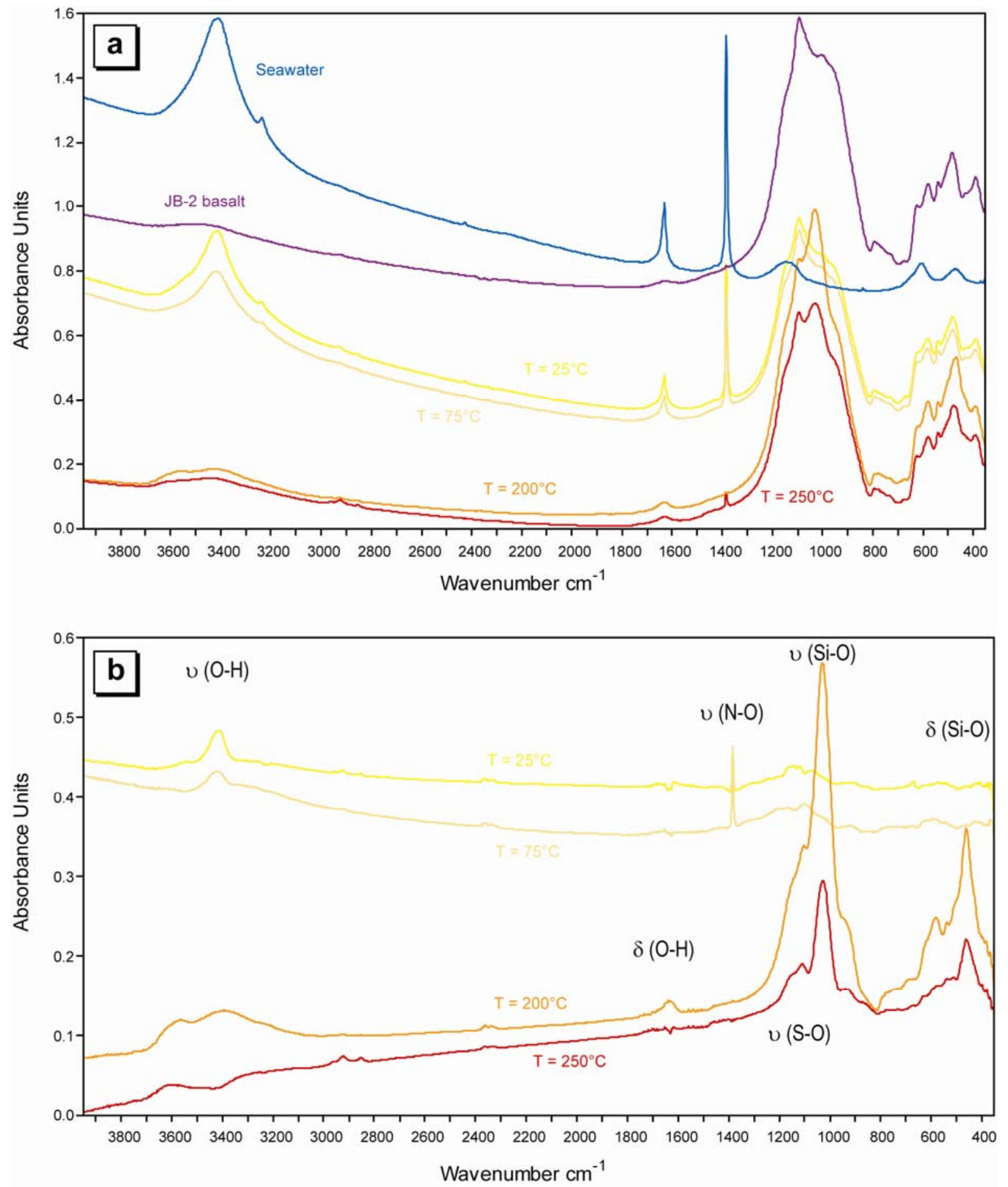
Figure 7
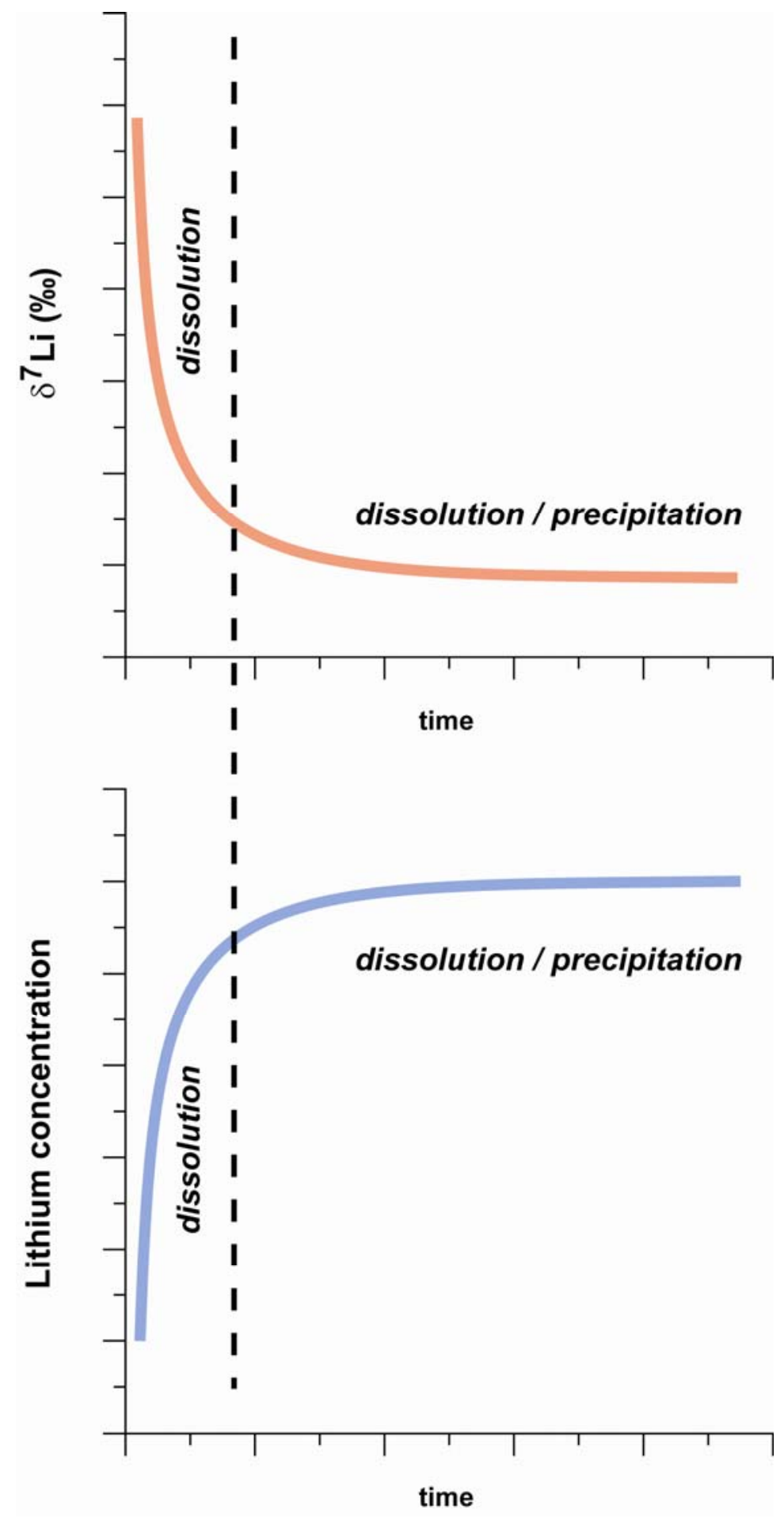


\section{Figure 8}

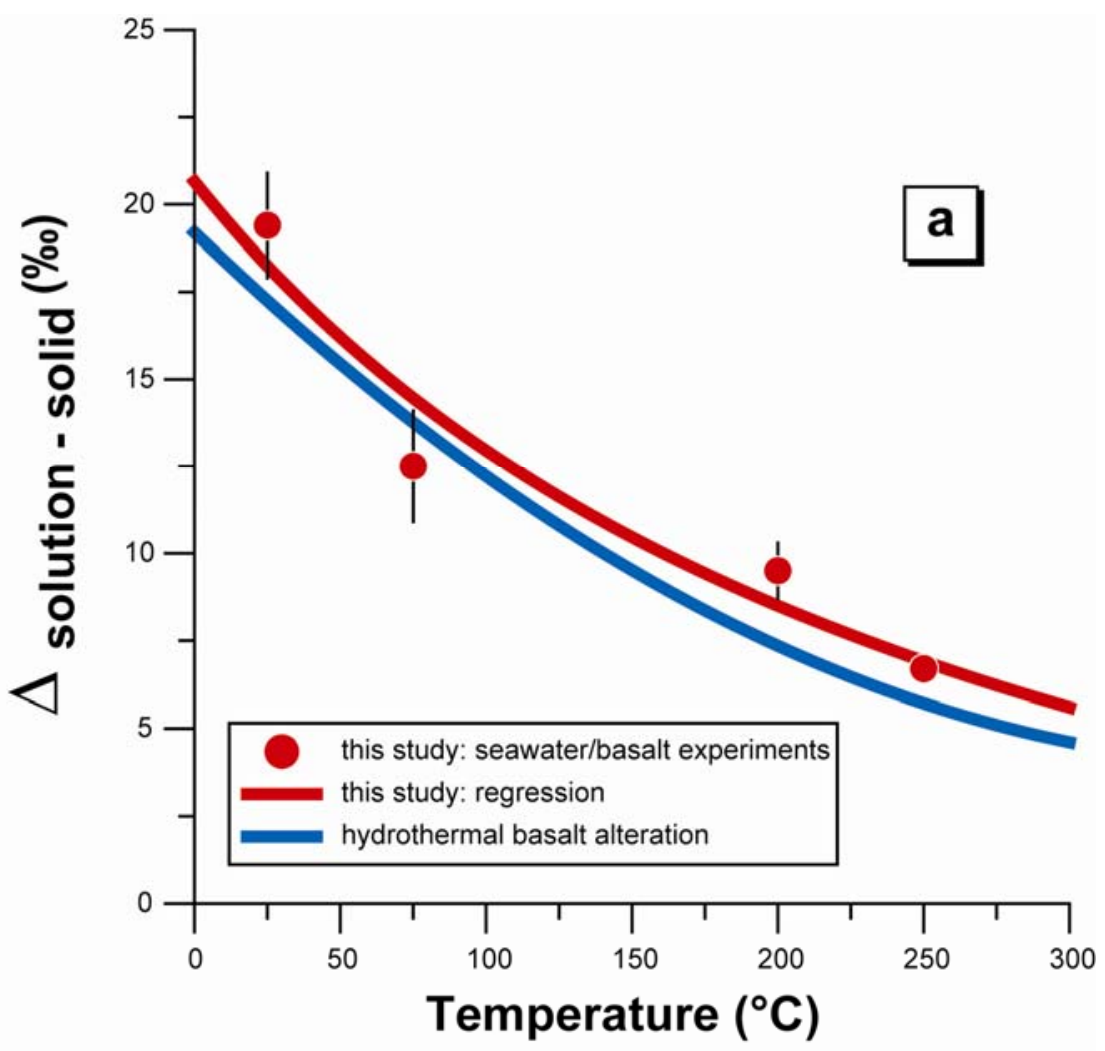

Temperature $\left({ }^{\circ} \mathrm{C}\right)$

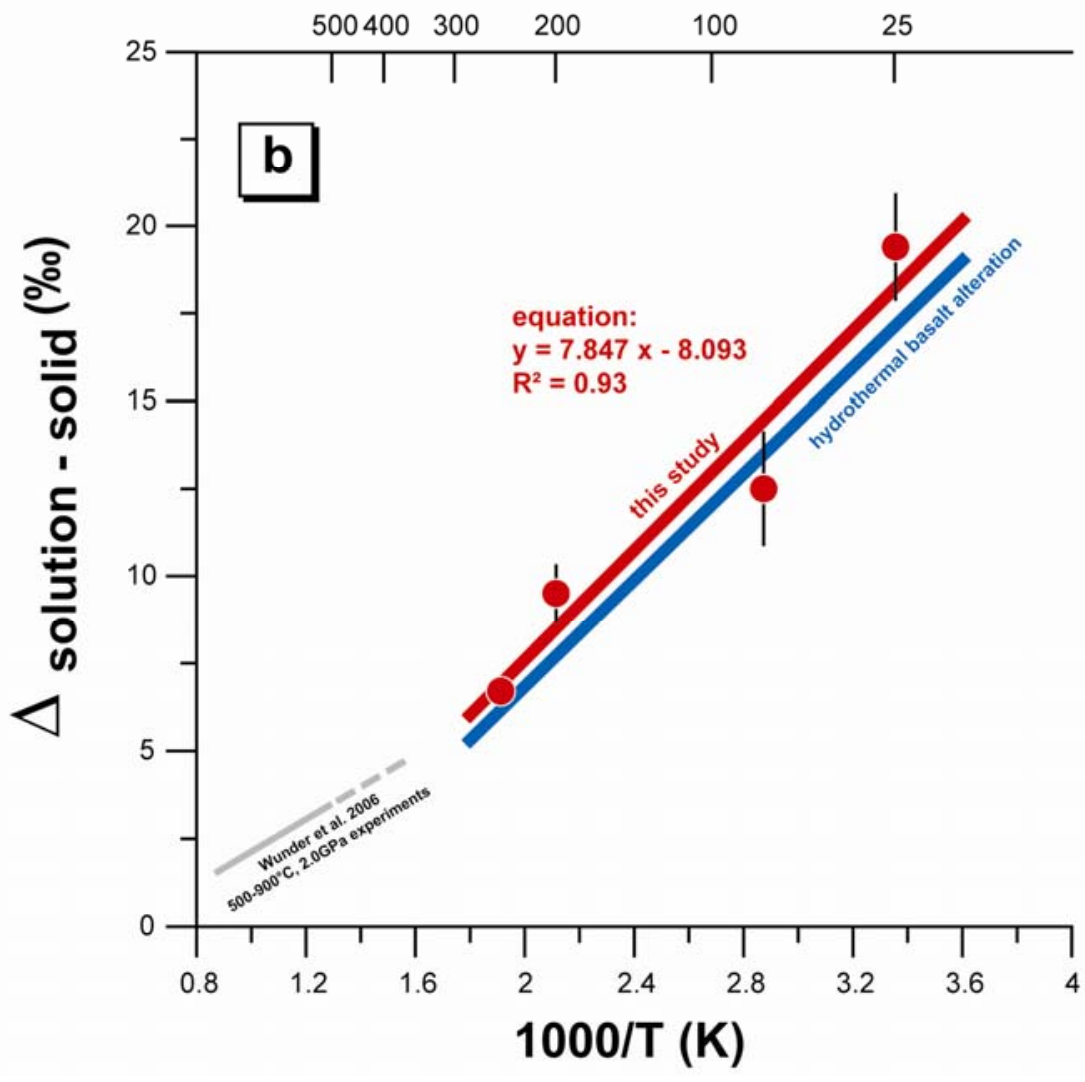


Figure 9

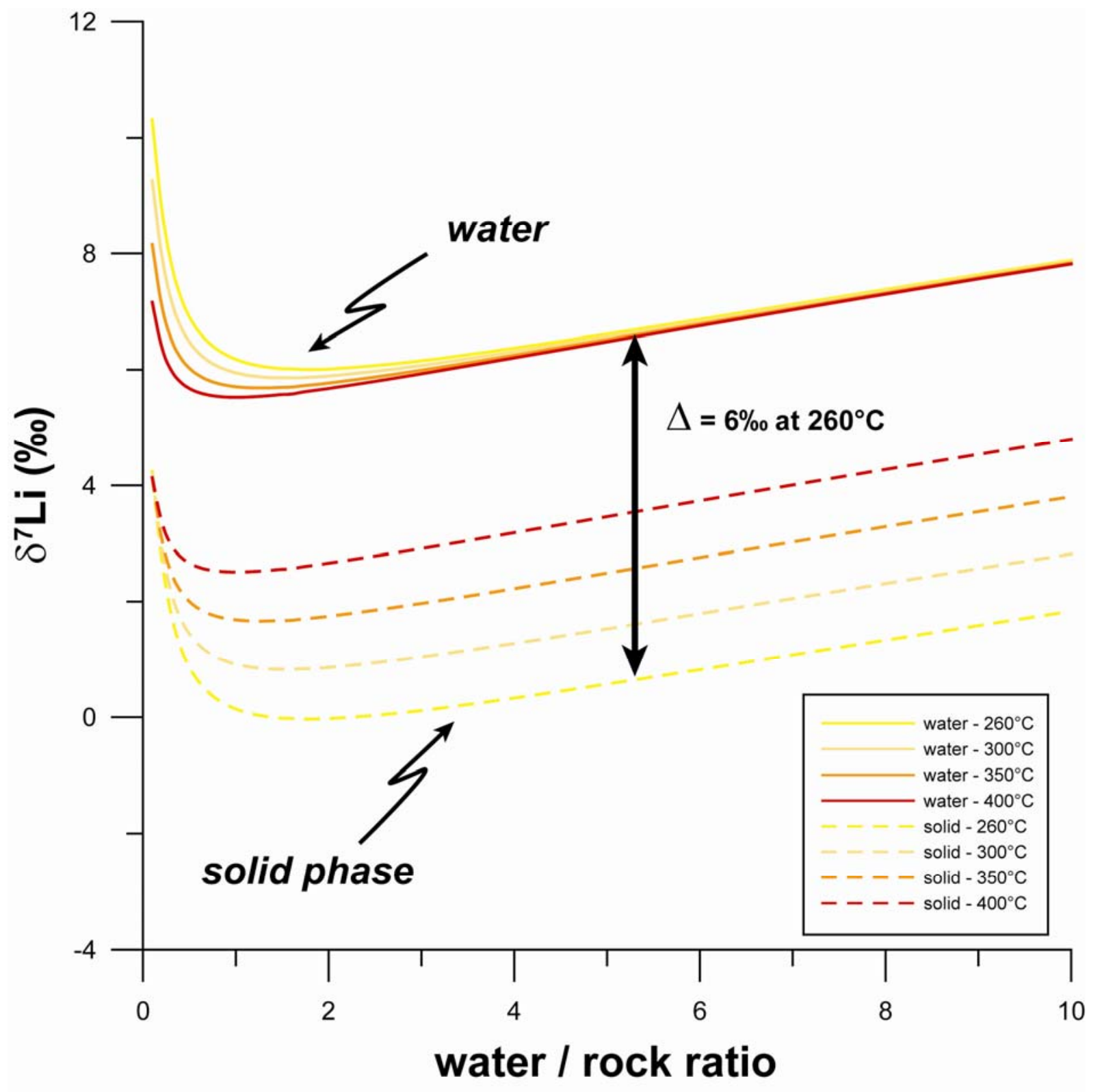


Figure 10

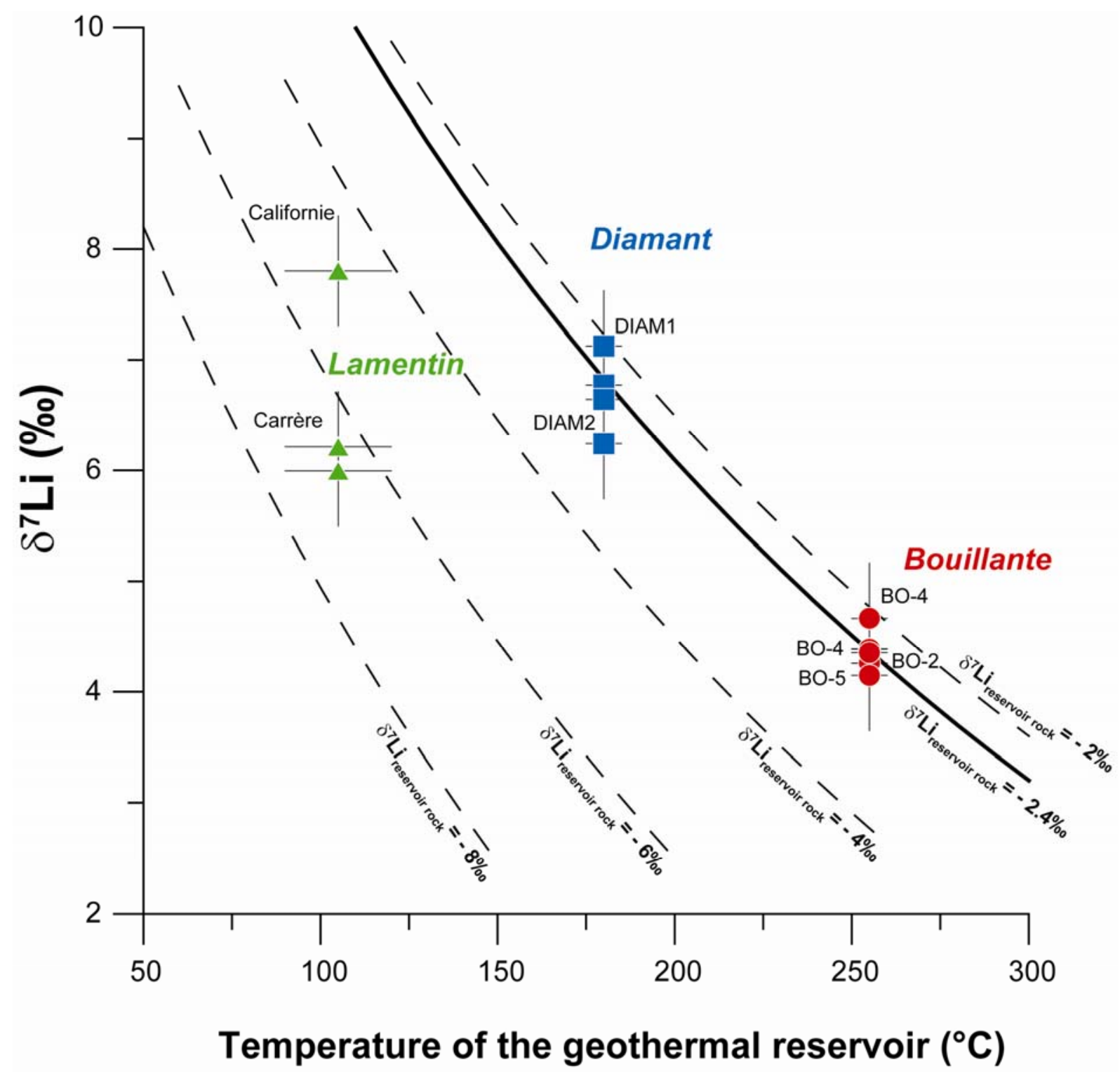


Table 1

\begin{tabular}{cccccc}
\hline $\begin{array}{c}\text { Temperature } \\
{ }^{\circ} \mathrm{C}\end{array}$ & Experimental device & $\begin{array}{c}\text { Run duration } \\
\text { days }\end{array}$ & $\begin{array}{c}\mathbf{L i} \\
\mu \mathrm{g} / \mathrm{L}\end{array}$ & $\begin{array}{c}\delta^{\mathbf{7}} \mathbf{L i} \\
\%\end{array}$ & $\mathbf{2} \sigma_{\mathrm{m}}$ \\
\hline $\mathbf{2 5}$ & PFA beaker in oven & 2 & 114 & 26.4 & 0.3 \\
& & 7 & 103 & 26.7 & 0.1 \\
& & 35 & 123 & 24.8 & 0.1 \\
& & 70 & 97 & 24.8 & 0.1 \\
& & 245 & 121 & 23.5 & 0.1 \\
\hline $\mathbf{7 5}$ & PFA beaker in oven & 2 & 116 & 22.6 & 0.1 \\
& & 7 & 150 & 20.9 & 0.1 \\
& & 35 & 166 & 17.8 & 0.1 \\
& & 70 & 158 & 17.9 & 0.1 \\
& & 245 & 220 & 16.5 & 0.1 \\
\hline $\mathbf{2 0 0}$ & PTFE bomb in oven & 3 & - & 14.5 & 0.1 \\
& & 7 & - & 14.5 & 0.1 \\
\hline $\mathbf{2 0 0}$ & Gold capsule in autoclave & 1 & 212 & 14.2 & 0.1 \\
& & 2 & 233 & 14.7 & 0.1 \\
& & 12 & 214 & 15.2 & 0.1 \\
\hline $\mathbf{2 5 0}$ & Gold capsule in autoclave & 1 & 284 & 13.1 & 0.3 \\
& & 2 & 316 & 11.7 & 0.1 \\
& & 7 & 352 & 11.6 & 0.1 \\
\hline
\end{tabular}




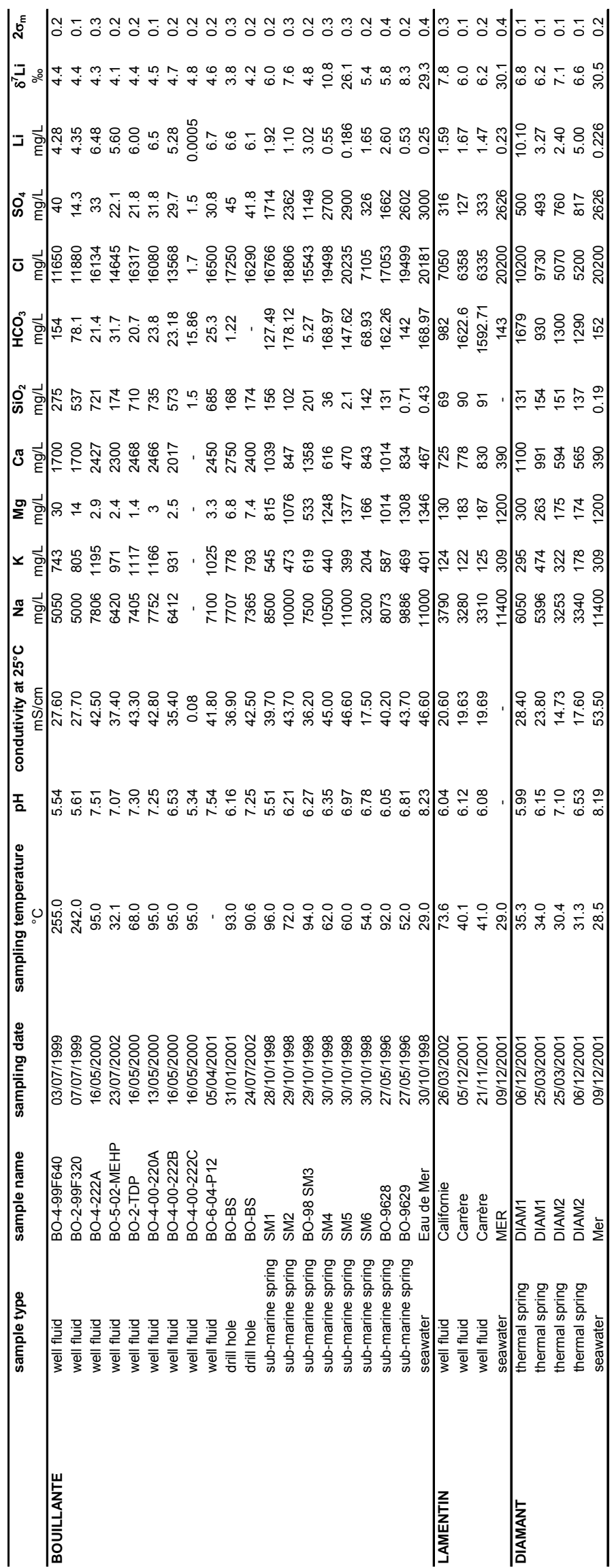




\section{Table 3}

\begin{tabular}{cccc}
\hline $\begin{array}{c}\text { Temperature } \\
{ }^{\circ} \mathbf{C}\end{array}$ & $\begin{array}{c}\delta^{\mathbf{7}} \mathbf{L i} \\
\text { solution }\end{array}$ & $\begin{array}{c}\boldsymbol{\delta}^{\mathbf{7}} \mathbf{L i} \\
\% \text { basalt }\end{array}$ & $\begin{array}{c}\Delta \text { solution - solid } \\
\% \text { o }\end{array}$ \\
\hline $\mathbf{2 5}$ & $24.4 \pm 1.5$ & 5.0 & 19.4 \\
$\mathbf{7 5}$ & $17.4 \pm 1.6$ & 4.9 & 12.5 \\
$\mathbf{2 0 0}$ & $14.6 \pm 0.8$ & 5.1 & 9.5 \\
$\mathbf{2 5 0}$ & $11.7 \pm 0.1$ & 5.0 & 6.7 \\
\hline
\end{tabular}

